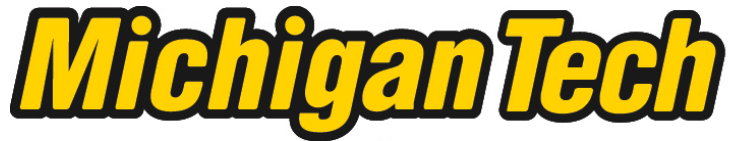 \\ Michigan Technological University Create the Future Digital Commons @ Michigan Tech
}

\section{Assessing land use and land cover change in tropical dry forest or Northern Chinandega, Nicaragua from 1985 to 2011}

Jonathan W. Malette

Michigan Technological University

Follow this and additional works at: https://digitalcommons.mtu.edu/etds

Part of the Forest Sciences Commons

Copyright 2012 Jonathan W. Malette

\section{Recommended Citation}

Malette, Jonathan W., "Assessing land use and land cover change in tropical dry forest or Northern Chinandega, Nicaragua from 1985 to 2011", Master's Thesis, Michigan Technological University, 2012.

https://doi.org/10.37099/mtu.dc.etds/169

Follow this and additional works at: https://digitalcommons.mtu.edu/etds

8 Part of the Forest Sciences Commons 


\title{
ASSESSING LAND USE AND LAND COVER CHANGE IN TROPICAL DRY FOREST OF NORTHERN CHINANDEGA, NICARAGUA FROM 1985 TO 2011
}

\author{
By \\ Jonathan W. Malette
}

\begin{abstract}
A THESIS
Submitted in partial fulfillment of the requirements for the degree of MASTER OF SCIENCE

In Forestry

MICHIGAN TECHNOLOGICAL UNIVERSITY

2012

(C)2012 Jonathan W. Malette
\end{abstract}


This thesis, "Assessing land use and land cover change in tropical dry forest of Northern Chinandega, Nicaragua from 1985 to 2011," is hereby approved in partial fulfillment of the requirements for the Degree of MASTER OF SCIENCE IN FORESTRY.

School of Forest Resources and Environmental Science

Thesis Advisor: $\quad$ Dr. Blair D. Orr

Committee Member: Dr. Ann Maclean

Committee Member: Dr. Alex Mayer

Committee Member: $\quad$ Dr. Linda M. Nagel

School Dean: $\quad$ Dr. Terry Sharik 


\section{TABLE OF CONTENTS}

LIST OF FIGURES................................................5

LIST OF TABLES..................................................7

ACKNOWLEDGEMENTS............................................8

ABSTRACT

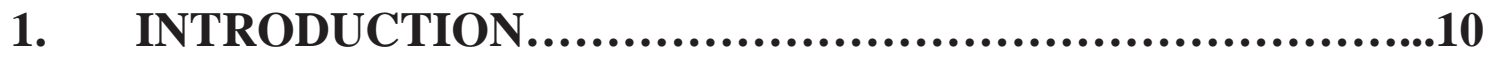

2. GENERAL BACKGROUND.....................................15

2.1. Climate and Topography.............................. 17

2.1.1. Physiographic Regions of Nicaragua....................18

3. METHODS.................................................23

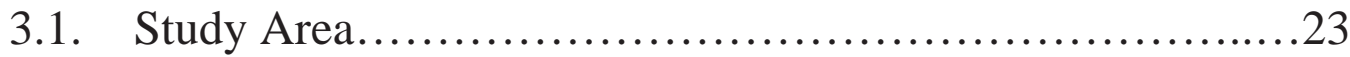

3.2. Data Acquisition........................................26

3.2.1. Satellite Images....................................26

3.2.2. Random Sample Points \& Groundtruthing.................27

3.3. Thematic Information Extraction........................29

3.3.1. Image Preprocessing.................................29

3.3.2. Image Transformation...............................29

3.3.3. Supervised Classification.............................30

4. $\quad$ RESULTS \& ANALYSIS ....................................36 
4.1. Results \& Analysis of Supervised Classification..............37

4.2. Results \& Analysis of Digital Change Detections............43

4.3. Results \& Analysis of Accuracy Assessment................55

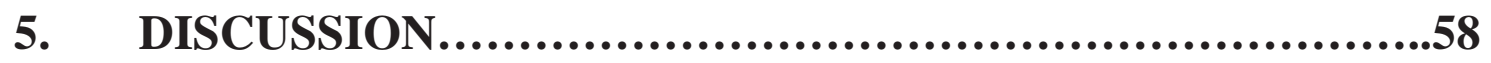

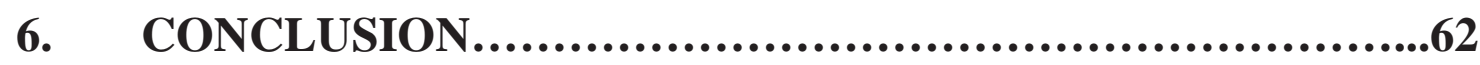

7. WORKS CITED................................................63

8. APPENDIX A........................................................67

9. APPENDIX B................................................69 


\section{LIST OF FIGURES}

Figure 1.1. The center of San Juan de Cinco Pinos. Photo by Jonathan W. Malette.11

Figure 1.2. A Family cultivating beans in Cinco Pinos. Photo by Jonathan W. Malette.................................................... 13

Figure 2.1. Map of Nicaragua and Central America..............................15

Figure 2.2. Political division map of Nicaragua..................................16

Figure 2.3. Physiographic regions of Nicaragua............................... 18

Figure 2.4. Mean annual rainfall in Nicaragua................................21

Figure 2.5. Distribution of the major forest types in Nicaragua...................22

Figure 3.1. Study site of Cinco Pinos, Chinandega...............................24

Figure 3.2. Fragmented TDF of Cinco Pinos study area: rainy season, August 2012. Photo by Jonathan W. Malette.....................................25

Figure 3.3. Random groundtruth point locations for Cinco Pinos.................28

Figure 3.4. LULCC detection map merged into two general change classes for Cinco

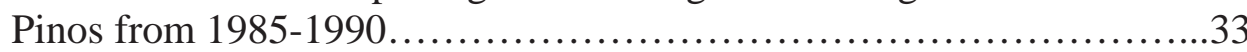

Figure 4.1. Supervised classification result of Cinco Pinos LULCC for 1985.......37

Figure 4.2. Supervised classification result of Cinco Pinos LULCC for 1990........38

Figure 4.3. Supervised classification result of Cinco Pinos LULCC for 1994........39

Figure 4.4. Supervised classification result of Cinco Pinos LULCC for 2000.......40

Figure 4.5. Supervised classification result of Cinco Pinos LULCC for 2007.......41

Figure 4.6. Supervised classification result of Cinco Pinos LULCC for $2011 \ldots . . . .42$

Figure 4.7. LULCC detection map merged into two general change classes for Cinco

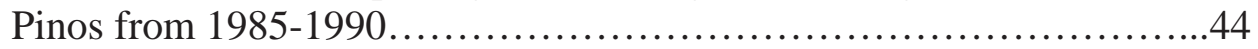

Figure 4.8. LULCC detection map merged into two general change classes for Cinco Pinos from 1990-1994............................................46

Figure 4.9. LULCC detection map merged into two general change classes for Cinco Pinos from 1994-2000...........................................48 
Figure 4.10. LULCC detection map merged into two general change classes for Cinco Pinos from 2000-2007.

Figure 4.11. LULCC detection map merged into two general change classes for Cinco Pinos from 2007-2011..............................................52

Figure 4.12. LULCC detection map merged into two general change classes for Cinco

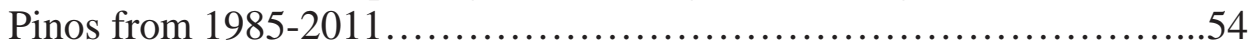

Figure 5.1. $\quad$ LULCC in hectares in Cinco Pinos for TDF, cultivated, and pasture from $1985-2011$ .58

Figure B.1. Fragmented TDF stand in Cinco Pinos. Photo by Jonathan W. Malette...69

Figure B.2. Fallow cultivated area in Cinco Pinos. Photo by Jonathan W. Malette...70

Figure B.3. Planted pasture grasses in Cinco Pinos. Photo by Jonathan W. Malette...71

Figure B.4. Agroforestry system of TDF under planted with coffee in Cinco Pinos. Photo by Jonathan W. Malette. . .72

Figure B.5. Plantation pine (Pinus oocarpa) in Cinco Pinos. Photo by Jonathan W. Malette .73

Figure B.6. Area allowed to return to shrub and brush in Cinco Pinos. Photo by Jonathan W. Malette. 


\section{LIST OF TABLES}

Table 3.1. Dates and scene numbers of Landsat 5 TM images...................27

Table 3.2. Land class codes and definitions for supervised classification of Cinco Pinos........................................................... 32

Table 4.1. LULCC in hectares (ha) in Cinco Pinos 1985-1990...................43

Table 4.2. Percent of LULCC in Cinco Pinos 1985-1990.........................44

Table 4.3. LULCC in hectares (ha) in Cinco Pinos 1990-1994....................45

Table 4.4. Percent of LULCC in Cinco Pinos 1990-1994_......................46

Table 4.5. LULCC in hectares (ha) in Cinco Pinos 1994-2000...................47

Table 4.6. Percent of LULCC in Cinco Pinos 1994-2000.........................48

Table 4.7. LULCC in hectares (ha) in Cinco Pinos 2000-2007....................49

Table 4.8. Percent of LULCC in Cinco Pinos 2000-2007.....................50

Table 4.9. LULCC in hectares (ha) in Cinco Pinos 2007-2011..................51

Table 4.10. Percent of LULCC in Cinco Pinos 2007-2011........................52

Table 4.11. LULCC in hectares (ha) in Cinco Pinos 1985-2011..................53

Table 4.12. Percent of LULCC in Cinco Pinos 1985-2011......................54

Table 4.13. Error matrix representing accuracy of supervised classification $2011 \ldots . .55$ 


\section{ACKNOWLEDGEMENTS}

First and foremost, I would like to thank my advisor Blair Orr for the invaluable guidance he provided me to complete this project. Without his experience and direction I would not have had the confidence to undertake such an endeavor. I like to say that he kept me in touch with "reality" as I spent two years in Nicaragua and developed a research topic.

I also owe considerable gratitude to my advisory committee. Without the assistance of Ann Maclean and her expertise in GIS and remote sensing, this project would not have been possible. Thank you as well to Linda Nagel and Alex Mayer for serving on my advisory committee and encouraging the best out of this project as a result of your valuable insights and recommendations.

To my Associate Peace Corps Director, Bayardo Etienne, and Project Specialist, Félix Cardoza, I would like to acknowledge their support and assistance as I balanced life as a Peace Corps volunteer and graduate student.

The people of San Juan de Cinco Pinos truly made me feel welcome in their community and in their homes. For their hospitality and interest in this project I am appreciative. Francisco "Paco" Martinez, Director of Natural Resources in Cinco Pinos, provided me with a wealth of knowledge regarding local environmental conditions and the history of the forests in the municipality.

Finally, I cannot thank my family and dear friends enough for all of your support and encouragement throughout my Peace Corps experience. All of your letters, phone calls, visits, and care packages meant more than you will know.

To these people I am truly thankful for their help in this accomplishment. 


\begin{abstract}
The objective of this study is to gain a quantitative understanding of land use and land cover change (LULCC) that have occurred in a rural Nicaraguan municipality by analyzing Landsat 5 Thematic Mapper (TM) images. By comparing the potential extent of tropical dry forest (TDF) with Landsat 5 TM images, this study analyzes the loss of this forest type on a local level for the municipality of San Juan de Cinco Pinos (63.5 $\mathrm{km}^{2}$ ) in the Department of Chinandega. Change detection analysis shows where and how land use has changed from 1985 to the present. From 1985 to 2011, nearly $15 \%$ of the TDF in San Juan de Cinco Pinos was converted to other land uses. Of the 1434.2 ha of TDF that was present in $1985,1223.64$ ha remained in 2011. The deforestation is primarily a result of agricultural expansion and fuelwood extraction. If current rates of TDF deforestation continue, the municipality faces the prospect of losing its forest cover within the next few decades.
\end{abstract}




\section{CHAPTER 1 - INTRODUCTION}

The people of Nicaragua are resilient. Political instability, widespread poverty, foreign intervention, frequent natural disasters, the toil of subsistence agriculture, and a recent civil war have made Los Nicaragüenses tough. But through these hardships, they have chosen not to harden their hearts. In few places will you be treated with such hospitality and open arms as in Nicaragua. When life presents obstacles, a crop fails, or a house is destroyed by a storm, Nicaraguans always find a way to start anew, rebuild, and carry on while remaining lighthearted. Many of the families I developed relationships with were grateful for what they had, and felt fortunate to have enough to eat, a house to sleep in, and to simply live in peace. They would have appreciated the opportunity to improve their lives if paying jobs would have been available, but since such opportunities were rare, they remained content with the lives they knew and the family they shared. In an impoverished situation, one must be resourceful and make do with what is accessible to survive and live with dignity. It is the resilience, resourceful nature, and contentment of the Nicaraguan people that have inspired me.

The topic of this thesis developed out the observations and experiences I had while living and working as a Peace Corps volunteer in the small Nicaraguan village of El Zacatón. I lived among families and learned from local leaders and campesinos sustaining a livelihood in one of the harshest environments I have ever observed. El Zacatón, in the foothills of the Botija Mountains, is located on the Pacific side of the country in the one of the smallest and poorest municipalities. The municipality of San 
Juan de Cinco Pinos (known commonly as Cinco Pinos) sits among three other small municipalities collectively referred to as the Cuatro Santos or Four Saints (Figure 1.1). This remote region, known to be one of the hottest in the country, is approximately 100 $\mathrm{km}$ from the department head, and about $240 \mathrm{~km}$ from Managua. Buses run daily to the capital, but few have the reasons or the means to travel there.

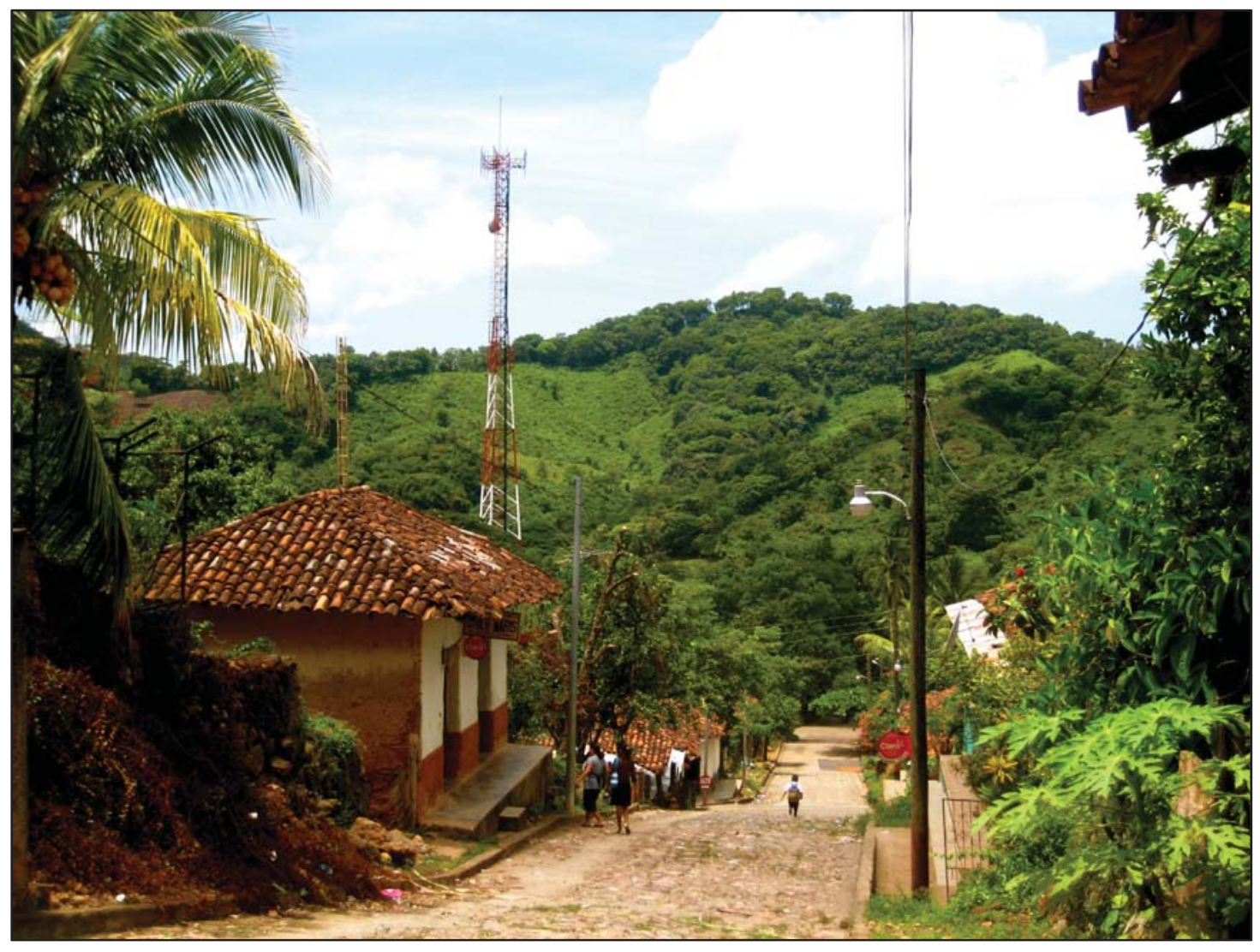

Figure 1.1. The center of San Juan de Cinco Pinos. Photo by Jonathan W. Malette. 
The rainy season occurs May to October and this is when farmers plant maize, beans, sorghum, and sesame (Figure 1.2). These basic grains are the staple foods upon which survival depends. Fruits and vegetables such as mango, papaya, plantain, tamarind, avocado, pipian, citrus, cashews, cacao, yucca, coconut, and caquisque are grown around the yard, or patio. Cattle, chicken, and pigs are common livestock. From November to April, the rains stop completely and the heat intensifies month by month until everyone spends afternoons lying in hammocks trying to escape the sweltering temperatures. The once intensely green vegetation of the deciduous tropical dry forest (TDF) dries up and blows away; leaving a dusty desolate landscape void of shade. Even by February, the evenings and nights provide little to no respite from the heat. Nearly all agricultural activities cease and many men leave town to seek work in Costa Rica or El Salvador as farm laborers. The monsoons of May and June are a welcome relief from the six-month drought. 


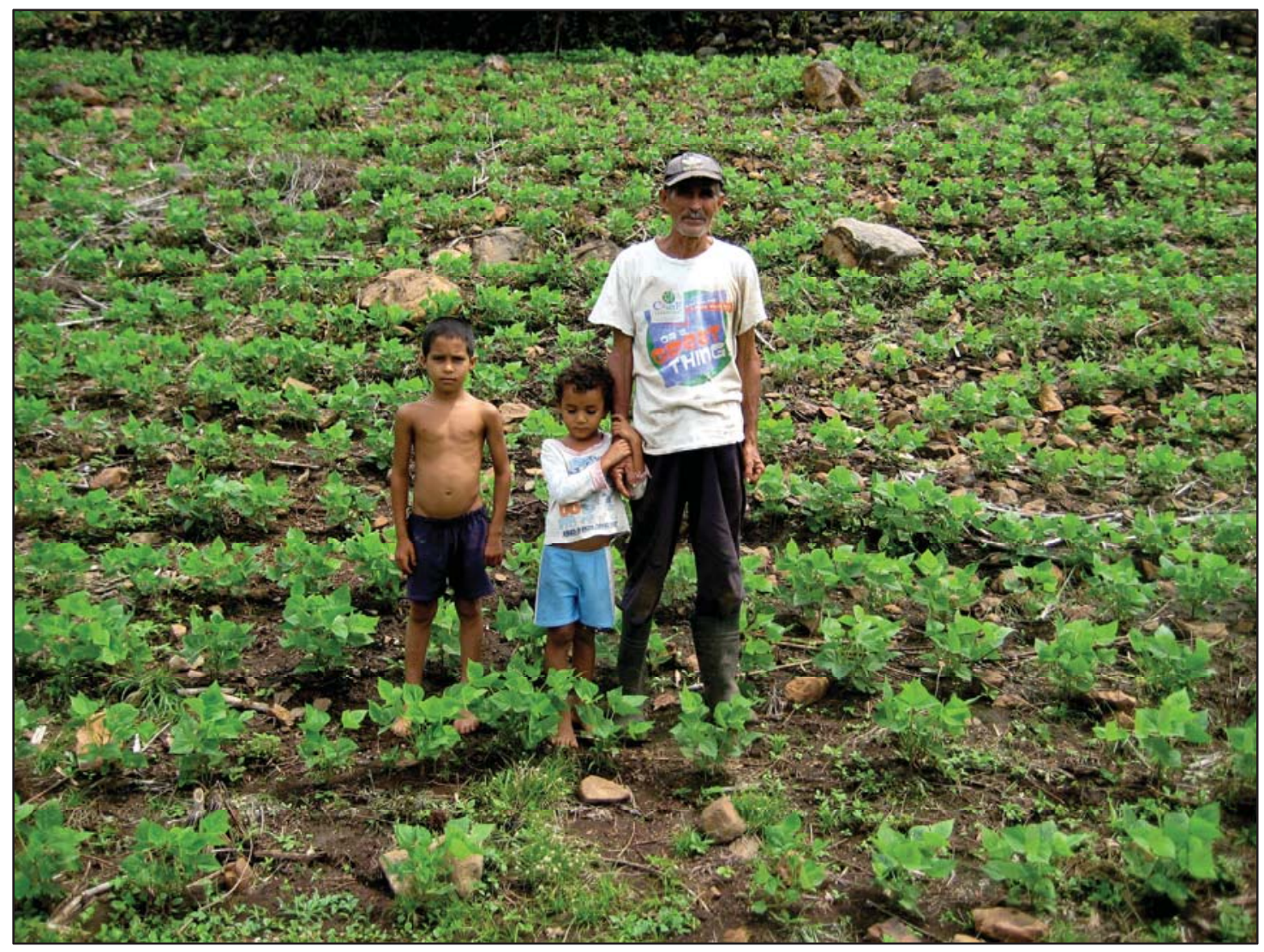

Figure 1.2. A family cultivating beans in Cinco Pinos. Photo by Jonathan W. Malette.

As an Agriculture and Sustainable Food Security Peace Corps volunteer, I worked closely with local farmers and families to develop practices that could improve food production and mitigate further deforestation of a degraded tropical dry forest. Initially, much of my time in the community was spent learning Spanish, developing relationships, and simply talking to people. After a few months people began inviting me to work with them, and together we started coming up with projects such as crop diversification, improved wood-fired ovens, and family tree nurseries. These were small-scale endeavors, but the benefit was that participation was genuine. Although I 
will never know exactly if and how my efforts benefited the people of Nicaragua, I have a sense that the small improvements I encouraged are part of a much larger collective effort of people seeking to invoke positive change throughout the world. 


\section{CHAPTER 2 - GENERAL BACKGROUND}

Distinguished as the largest country in Central America, the Republic of Nicaragua is located south of Honduras and north of Costa Rica (Figure 2.1) (CIA 2012). Nicaragua has $910 \mathrm{~km}$ of coastline, bordering both the North Pacific Ocean and the Caribbean Sea (CIA 2012). The total area of Nicaragua is 130,370 square kilometers, slightly smaller than the state of New York (CIA 2012).

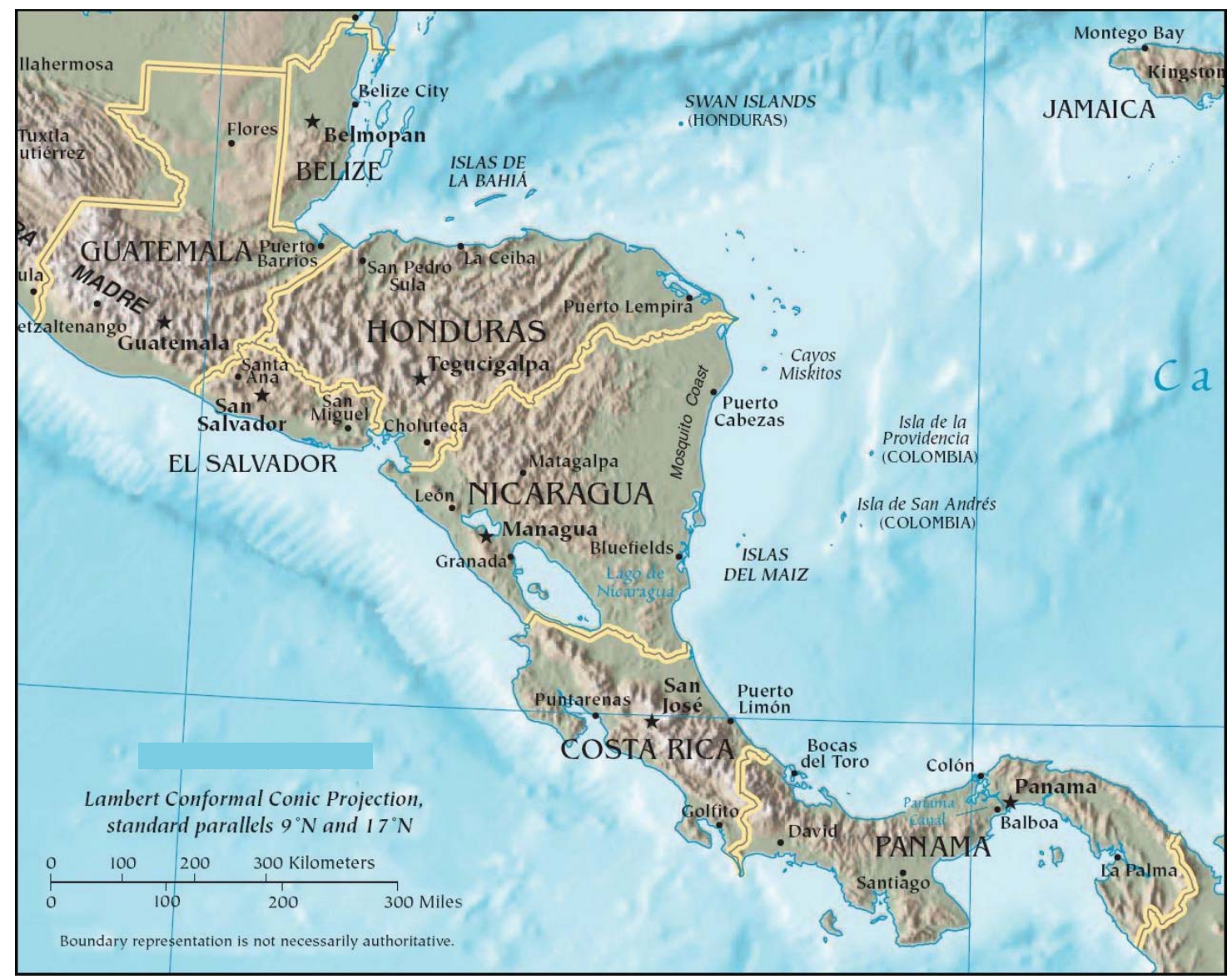

Figure 2.1. Map of Nicaragua and Central America (CIA 2012). Map courtesy of CIA. 
Nicaragua is divided into fifteen departments: Boaco, Carazo, Chinandega, Chontales, Esteli, Granada, Jinotega, Leon, Madriz, Managua, Masasya, Matagalpa, Nueva Segovia, Rio San Juan; and two autonomous regions: The Autonomous Region of the North Atlantic (RAAN) and the Autonomous Region of the South Atlantic (RAAS) (Figure 2.2) (ENABAS 2012).

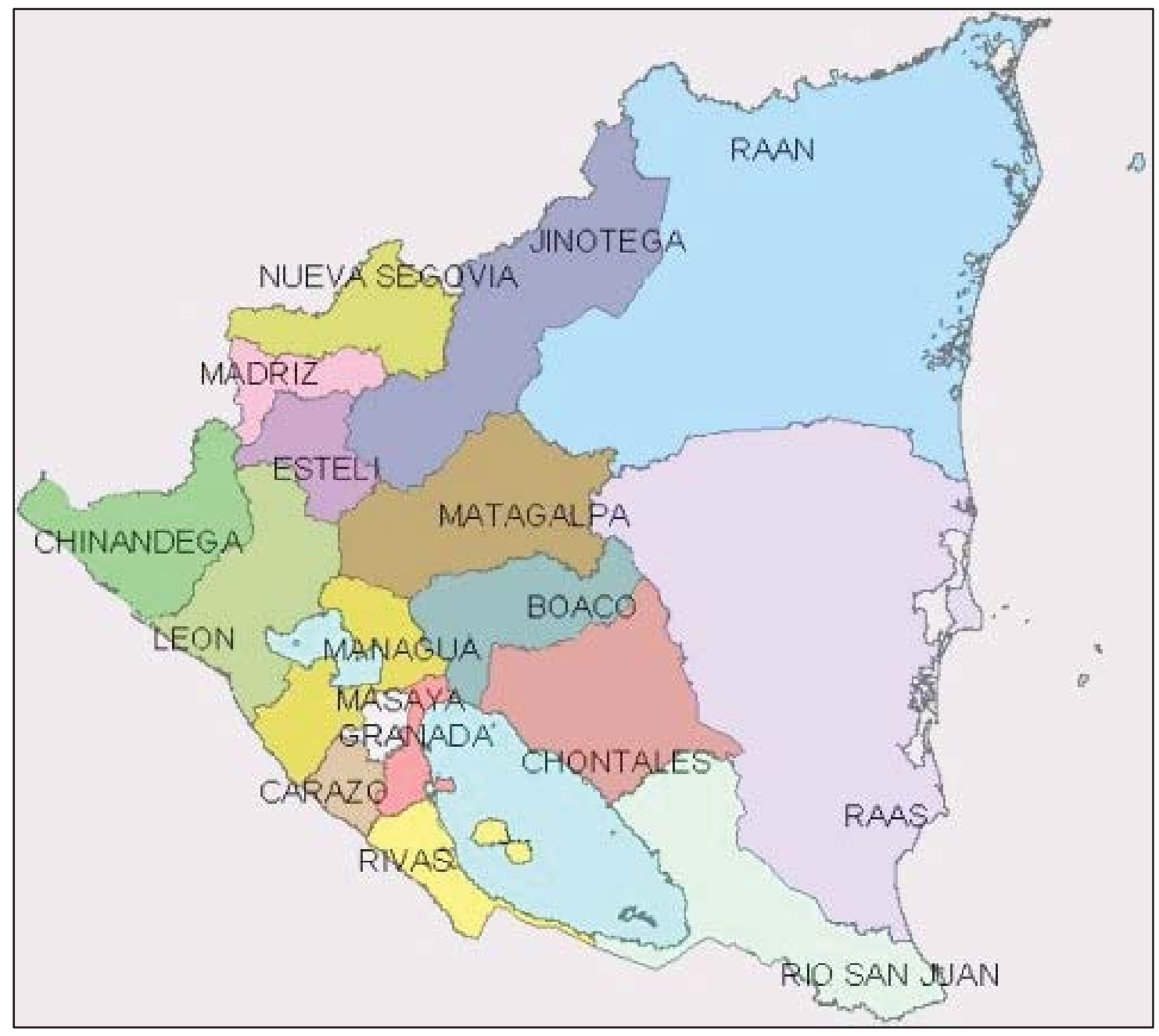

Figure 2.2. Political division map of Nicaragua (ENABAS 2012). Map courtesy of ENABAS. 
The departments and autonomous regions are further divided into 153 municipalities (INETER 2012). Managua is the largest city and capital of Nicaragua. The population of Nicaragua is 5,727,707 persons of which 934,000 live in the capital city of Managua (CIA 2012). Nicaragua has the lowest population density of Central American countries at 48 persons per square kilometer (Encyclopaedia Britannica Online 2012). The rate of urbanization is increasing by two percent annually (CIA 2012) with 57 percent of the population residing in an urban setting (Library of Congress Online Catalog 2012).

\subsection{Climate and Topography}

Nicaragua is located in the Tropics between $10^{\circ} 45^{\prime} \mathrm{N}$ and $15^{\circ} 05^{\prime} \mathrm{N}$ and $83^{\circ} 15^{\prime} \mathrm{W}$ and 87²40'W (CIA 2012). Known as La Tierra de Lagos y Volcanos (The Land of Lakes and Volcanos), Nicaragua is home to two large freshwater lakes: Lago de Managua and Lago de Nicaragua, which is the largest in Central America. The country has 40 major volcanic formations including 28 volcanoes and 8 crater lakes (Siebert and Simkin 2002). Hence, the region is subject to frequent seismic activity. Devastating earthquakes flattened Managua in 1931 and again in 1972 (Library of Congress Online Catalog 2012). The most recent significant volcanic activity occurred on September 8, 2012, when San Crístobal erupted gas and ash $4 \mathrm{~km}$ into the atmosphere forcing about 3,000 people to evacuate from the Department of Chinandega (Silva 2012). Nicaragua is also exposed to tropical monsoons and hurricanes that arrive from the Caribbean Sea (INETER 1998). 


\subsubsection{Physiographic Regions of Nicaragua}

Nicaragua consists of three main life zones: the hot and dry Pacific lowlands; the cooler, wetter central highlands; and the rainy lowlands of the Caribbean (Figure 2.3) (Holdridge 1967).

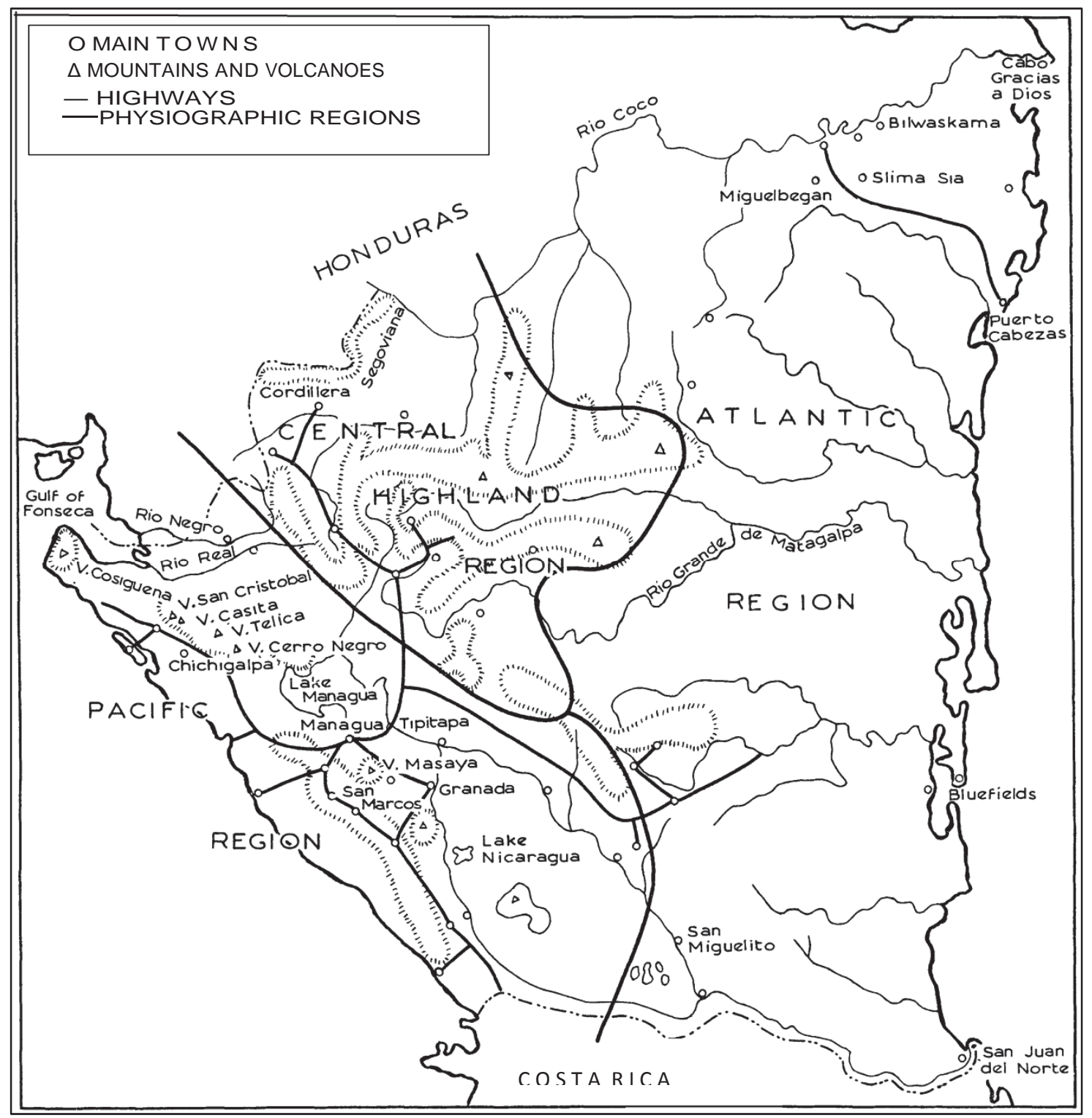

Figure 2.3. Physiographic regions of Nicaragua (Taylor 1963). Reprinted with permission by Verity Butler (Permissions Co-coordinator, Wiley). 


\section{Pacific Lowlands}

The lowlands of the Pacific $(\leq 750 \mathrm{~m})$ are mostly flat except for a chain of active volcanoes that stretch from the Golfo de Fonseca to Lago de Nicaragua (Library of Congress Online Catalog 2012). Mean daytime temperatures vary between $30^{\circ} \mathrm{C}$ and $33^{\circ} \mathrm{C}$. Nighttime temperatures generally range from $20^{\circ} \mathrm{C}$ to $24^{\circ} \mathrm{C}$. The Pacific coastal region is characterized by a rainy season from May to October and a dry season from November to April (Perez et al. 2007). Total annual rainfall ranges from 500mm 1,500mm (Figure 2.4) (Perez et al. 2007). The distinct decrease in rainfall from the middle of July to the middle of August is known colloquially as la canicula or "the heat wave" (Ramirez 2005). Seasonal moist forest, TDF, and fertile lowland plains characterize this region (Figure 2.5). Mangroves are found adjacent to Golfo Fonseca (WWF 2012).

\section{Tropical Dry Forest}

Seasonally deciduous tropical dry forests or tropical dry forests (TDF) receive 250 to $2000 \mathrm{~mm}$ of annual rainfall, require mean annual temperatures greater than $17^{\circ} \mathrm{C}$, and have an annual ratio of potential evapotranspiration to precipitation of less than 1.0 (Dirzo et al. 2011). The single most defining characteristic of TDF is a seasonal drought of $4-6$ months that receives $<100 \mathrm{~mm}$ of precipitation. This period of drought causes the trees to shed their leaves during the dry season and maintain evergreen characteristics during the rainy season. 
TDFs are the second largest tropical forest type (Miles et al. 2006), yet are disproportionally less studied than tropical rain forests. This scientific bias limits our understanding of the tropical forest biome and the anthropogenic threats to it (SanchezAzofeifa et al. 2005). The study and conservation of TDF is considered essential due to their high biological diversity, and uneven distribution across tropical regions. The Neotropical and Caribbean regions are home to the greatest distributions of TDF, which is considered the region's most threatened tropical forest. At least 48 percent of the original extent of TDF in this region has been converted to other land uses with a substantial proportion of remaining TDF fragmented to various degrees (Miles et al. 2006). TDF of Central America are especially threatened given that only $6 \%$ has protected area status (Miles et al. 2006).

\section{Central Highlands}

The terrain of the central highlands varies greatly with elevations from $750 \mathrm{~m}$ to $1,800 \mathrm{~m}$ (Library of Congress Online Catalog 2012). The peaks of this region protect the Pacific

lowlands from the Caribbean moisture systems, and can receive 1,000 to 1,500 $\mathrm{mm}$ of annual rainfall. Daytime temperatures in the highlands vary between $22{ }^{\circ} \mathrm{C}$ and $27{ }^{\circ} \mathrm{C}$, and between $15{ }^{\circ} \mathrm{C}$ and $24{ }^{\circ} \mathrm{C}$ at night. Both Pine-Oak Forest and Montane Forest cover the ridges and valleys of the highlands (WWF 2012). 


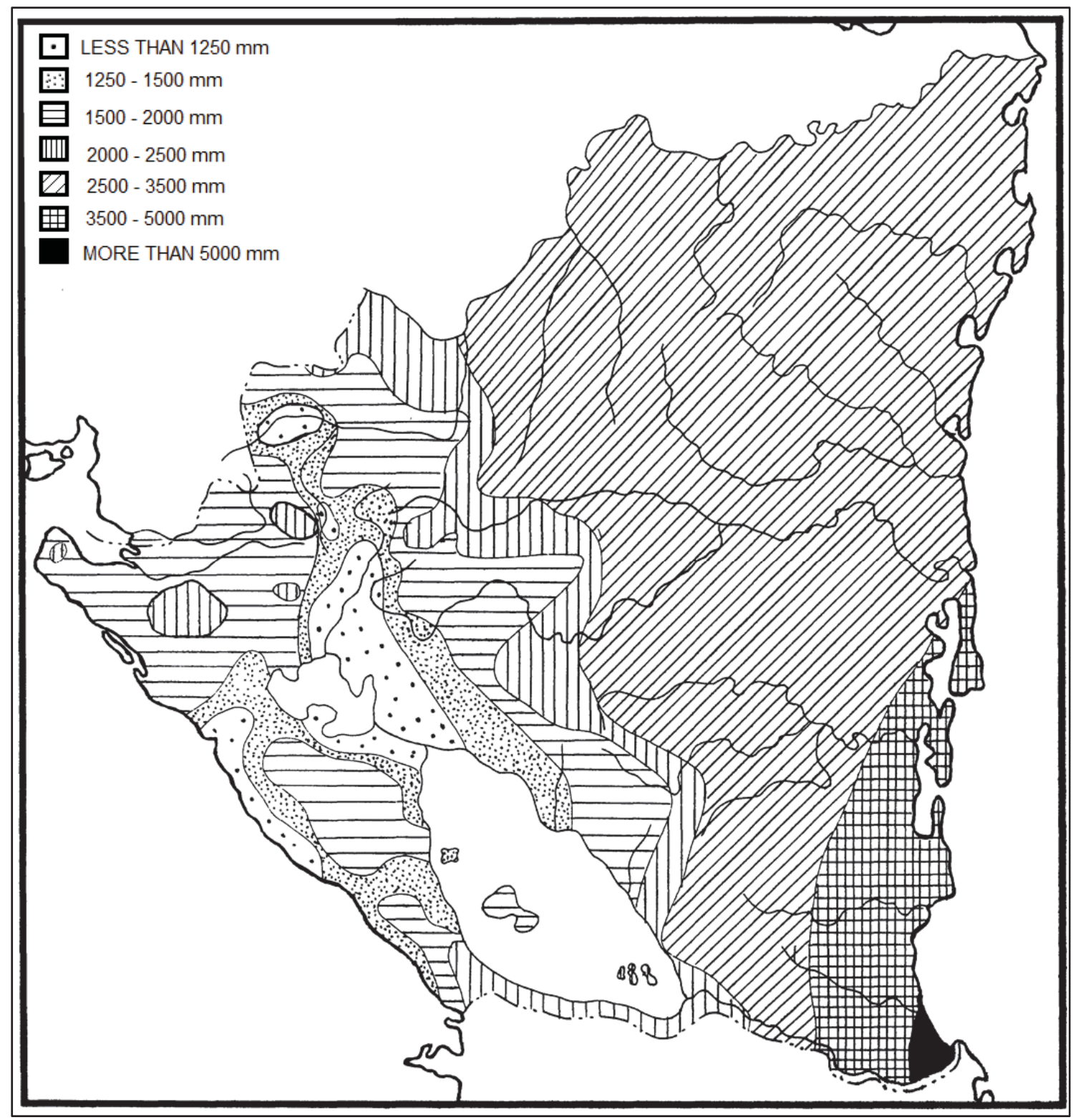

Figure 2.4. Mean annual rainfall in Nicaragua (Taylor 1963). Reprinted with permission by Verity Butler (Permissions Co-coordinator, Wiley).

\section{Atlantic Region}

The eastern Caribbean lowlands of the Atlantic region account for more than $50 \%$ of the country's territory yet are sparsely populated (Library of Congress Online Catalog 2012). This hot and humid region is also the wettest, receiving 2,500-6,500 $\mathrm{mm}$ of rain 
annually. Varying in elevation from sea level to about 750 masl at the eastern edges of the central highlands, mean temperatures range from $24{ }^{\circ} \mathrm{C}$ to $33{ }^{\circ} \mathrm{C}$ (Ramirez 2005). Moist forests, Caribbean pine forests, and extensive alluvial plains cover the Atlantic coast (WWF 2012)

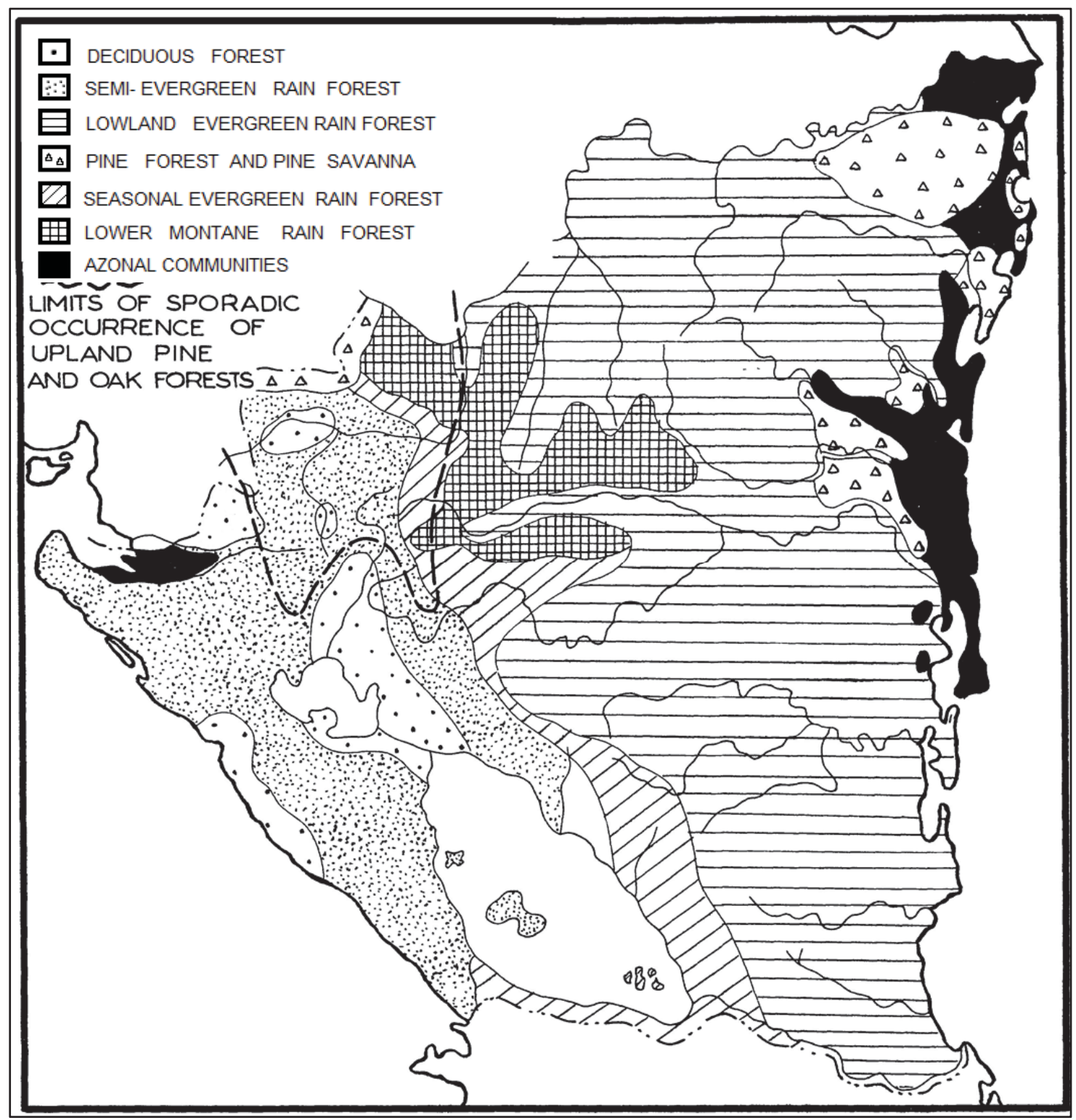

Figure 2.5. Distribution of the major forest types in Nicaragua (Taylor 1963). Reprinted with permission by Verity Butler (Permissions Co-coordinator, Wiley). 


\section{CHAPTER 3 - METHODS}

The objective of this study was to gain a quantitative understanding of the land use and land cover changes (LULCC) in the municipality of San Juan de Cinco Pinos, Department of Chinandega, Nicaragua by analyzing Landsat 5 Thematic Mapper (TM) images from 1985, 1990, 1994, 2000, 2007, and 2011. I utilized a supervised classification technique to sort and define spectral signatures in the imagery for eight land cover classes. Change detection analyses were performed to compare the quantities and locations of land class conversions between time intervals. Groundtruthing was performed in February, March, and April of 2012 to validate data. An accuracy assessment determined overall classification accuracy to be $87.60 \%$. ArcGIS 10.1 and ERDAS IMAGINE Version 11 were utilized for the digital image processing and GIS analyses.

\subsection{Study Area}

The study area covers the municipality of San Juan de Cinco Pinos in the Department of Chinandega. The total area of Cinco Pinos is $63.5 \mathrm{~km}^{2}$ (INETER 1998). Cinco Pinos is located in the NW corner of Nicaragua in a region known as the Cuatro Santos (Four Saints) that also includes the adjacent municipalities of San Pedro del Norte, San Francisco del Norte, and Santo Tomas (Figure 3.1) 


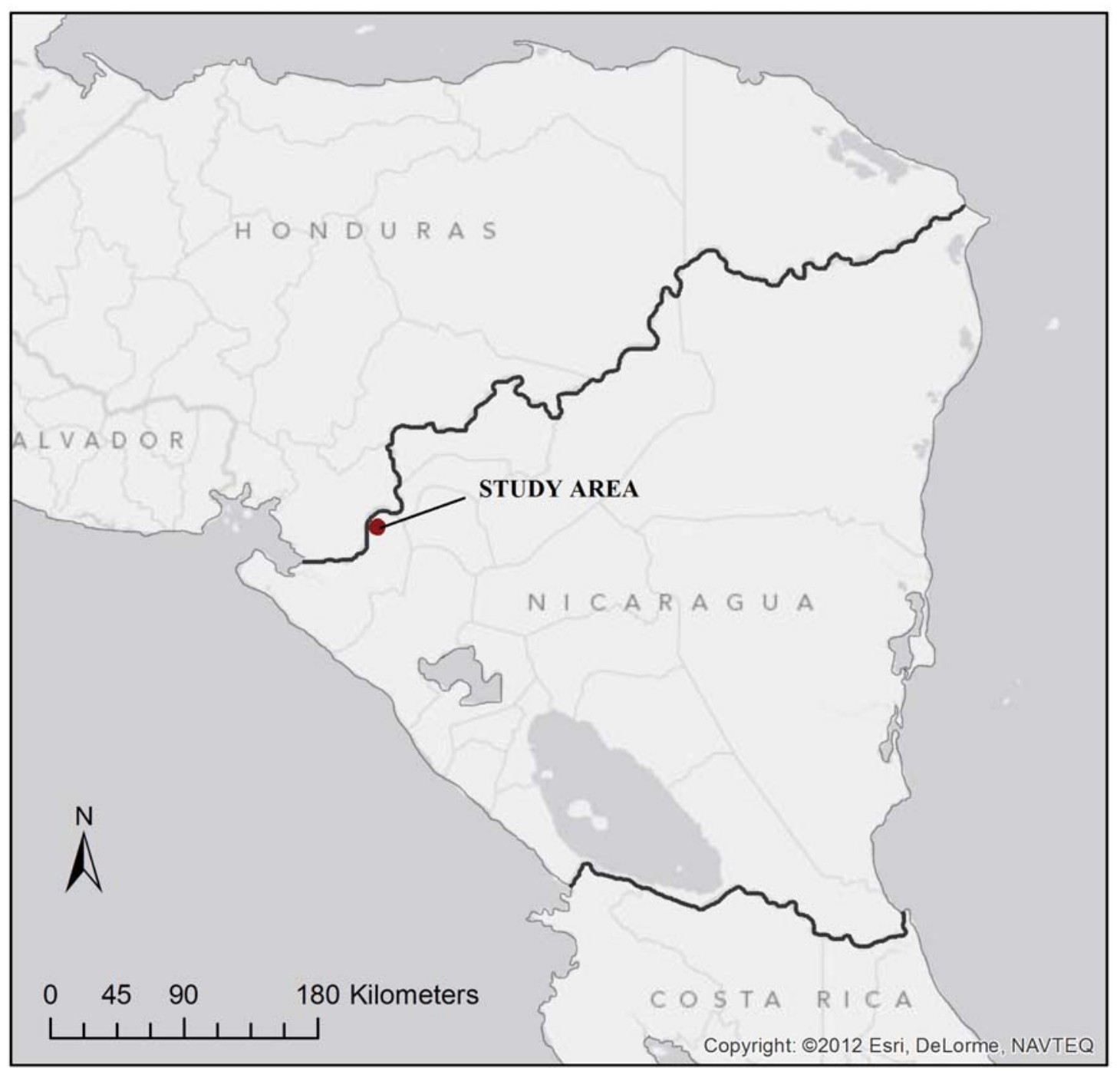

Figure 3.1. Study site of Cinco Pinos, Chinandega (ESRI et al. 2012). Reprinted with permission.

The municipality of Cinco Pinos, located at elevations between 400-600 masl, is situated at the foothills of the Botija Mountains (CIA 2012). The topography of the region is dominated by extensive areas of mountainous terrain with remnants of pine (Pinus oocarpa) forests and small valleys exploited for agriculture and livestock (Figure 
3.2). Slopes range from 5-60\%. TDF characterizes the region (Salas Estrada 1993). The climate is tropical with a distinct dry season of 4-6 months from November-April and a wet season from May-October. Annual precipitation varies between $800 \mathrm{~mm}$ $1000 \mathrm{~mm}$ with an average temperature of $28^{\circ} \mathrm{C}$ (INETER 1998).

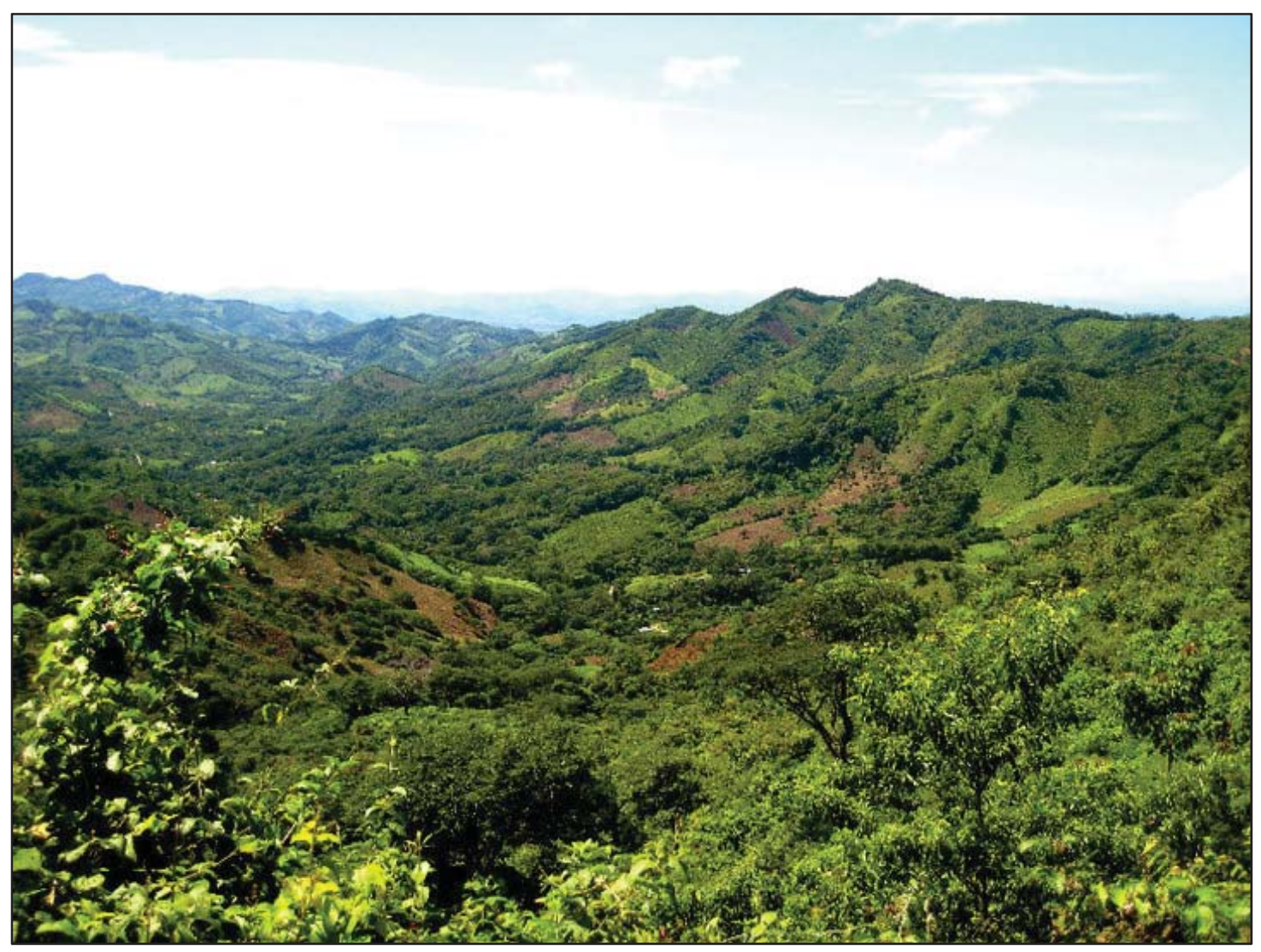

Figure 3.2. Fragmented TDF of Cinco Pinos study area: rainy season, August 2012. Photo by Jonathan W. Malette. 


\subsection{Data Acquisition}

\subsubsection{Satellite Images}

Various types of satellite imagery are available for the purpose of remote sensing of LULCC, however, when conducting studies to monitor time series of LULCC, Landsat imagery is preferable because the temporal resolution coupled with the near and mid infrared bands allows close examination of vegetation and other landscape features (Zeledon and Kelly 2009). The Landsat 5 TM sensor system was launched on March 1, 1984 and continues to record energy in the visible, near-infrared, mid-infrared, and thermal-infrared areas of the spectrum (Jensen 2005). TM data are sensed in these seven spectral bands simultaneously and has a $30 \mathrm{~m}$ spectral resolution. Images used for this study were obtained from the USGS Earth Explorer database (http://earthexplorer.usgs.gov/). I identified six Landsat 5 TM images (Table 3.1) to be relatively cloud free and provide 4-5 year intervals allowing me to monitor the rate, direction, and type of LULCC. 
Table 3.1. Dates and scene ID numbers of Landsat 5 TM Images.

\begin{tabular}{cc}
\hline \multicolumn{1}{c}{ Date } & L4-5 TM Entity ID \\
\hline 01-Feb-85 & LT50170511985032XXX08 \\
03-Mar-90 & LT50170511990062XXX02 \\
26-Feb-94 & LT50170511994057XXX02 \\
10-Jan-00 & LT50170512000010XXX03 \\
10-Sep-07 & LT50170512007253CHM00 \\
08-Jan-11 & LT50170512011008CHM00 \\
\hline
\end{tabular}

\subsubsection{Random Sample Points and Groundtruthing}

Using ancillary data as a reference, the municipality of Cinco Pinos was digitized using the Editor function in ArcMap. Following Zeledon and Kelly (2009), 150 stratified random sample points were generated within the study area with the Create Random Points tool in ArcGIS to obtain an equal representation of land classes (Figure 3.3). The points were transferred to a handheld GPS unit (Garmin $72 \mathrm{H})$, and each location was physically visited in February, March, and April of 2012 to determine current land use. Because few (<3) agroforestry land classes and no pine forests were represented by the stratified random points, eight additional data points in agroforestry systems (coffee cultivated beneath mature forest cover) and four additional sample points were collected in pine forests. A digital photograph was taken at each point for reference and assistance in LULCC definition. 


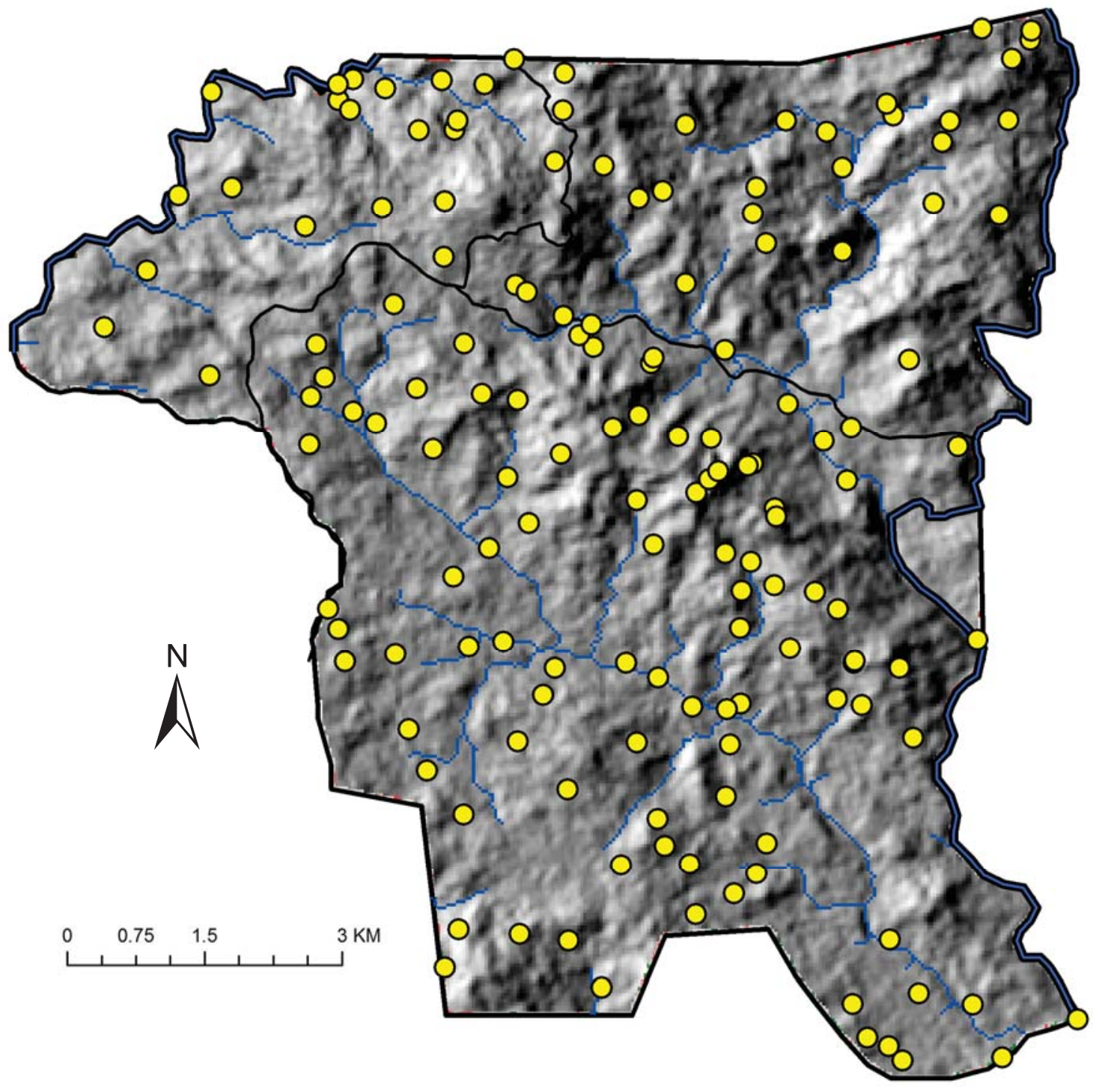

Figure 3.3. Random groundtruth point locations for Cinco Pinos. 


\subsection{Thematic Information Extraction}

\subsubsection{Image Preprocessing}

The individual bands for each image were converted from Tagged Image Format File (.TIFF) to Image (.IMG) formats in ArcGIS and combined to create the six separate composite images listed in Table 3.1. The images are registered to the World Geodetic System (WGS) 1984 and projected in UTM Zone 16N. The short-wave infrared band was not utilized in the analysis because its capability detecting hydrothermally altered rocks associated with mineral deposits is not relevant to this study.

\subsubsection{Image Transformation}

Principal Component Analysis

Principal component analysis (PCA) is a widely utilized procedure to analyze time series data (Press et al. 1992; Wang 1993). Original remotely sensed imagery can be transformed into principal component images which are usually considered to be more easily and accurately classified as the components are uncorrelated (Singh and Harrison 1985). The components represent most of the information present in the original dataset. The transformation is such that the first principal component accounts for the maximum proportion of the variance of the original dataset and subsequent orthogonal components account for the maximum proportions of the remaining variance (Zhao and Maclean 2000). PCA transformations were calculated for each of the six images in IMAGINE. The PCA images were utilized to derive training sites, and inputs in the 
supervised classification. All of the components for each image were utilized in the supervised classification process.

\subsubsection{Supervised Classification}

\section{Training Sites}

A training site is an area where the land class has been identified, and the spectral characteristics used to train the classification algorithm to group spectrally similar values for the entire image (Jensen 2005). For each TM image, 162 training sites were created from the groundtruth data. We identified six LULC classes: TDF, pine forest, agroforestry, brush, cultivated, and pasture. Clouds and cloud shadows, when present, were also mapped.

\section{Evaluation of Training Sites: Contingency Matrix}

Once training sites for the LULC plus clouds and cloud shadows, if present, were constructed, the utility of the training sites was evaluated. Ideally, all of the pixels within the training sites will be classified as the chosen LULC. However, pixels within each training site are not always homogeneous enough to the point where every pixel is actually classified to its corresponding class. To determine the purity of each training site, a classification of only the pixels contained within the training sites was performed using a maximum likelihood decision rule, and a contingency matrix constructed which contained the number and percentages of pixels that were classified as anticipated (ERDAS Field Guide 2010). Training sites classified with multiple land cover classes 
were deleted, and statistically similar training sites were merged and given the same LULC name. Additional training sets were taken and evaluated as needed.

\section{Supervised Classification}

Multispectral classification is a commonly utilized method to extract thematic information from remotely sensed data. A supervised classification is an approach, which uses training site statistics to assign a LULC value to every pixel in the image. The choice of a particular classifier depends on the nature of the input imagery and the required output (Jensen 2005). The maximum likelihood classifier (MAXLIKE) is the most widely used supervised classification algorithm and its decision rule is based on probability. The algorithm assigns each pixel to the training site that has the highest probability of membership. It was chosen for this study as the LULC spectral signatures do have some degree of overlap and are not well separated in feature space. MAXLIKE utilizes the means, standard deviations, covariance matrices, and correlation matrix calculated for each site. For every pixel $X$, the probability of membership in each class $c$ is calculated using the calculation where $p(X \mid c)$ is the probability density function for a pixel $X$ as a member of class $c, a_{c}$ is the beforehand probability of membership of class $c$, and $m$ is the total number of classes:

$$
\begin{aligned}
L(c \mid X)= & \underline{a_{c}} \underline{p(X \mid c)} \\
& \sum_{r=1}^{m} a_{r} p(X \mid r)
\end{aligned}
$$

After the supervised classification was completed, the images were recoded using the Thematic Recode tool IMAGINE to the six LULC classes and two cloud classes when present (Table 3.2). 
Table 3.2. Land class codes and definitions for supervised classification of Cinco Pinos.

\begin{tabular}{|c|c|c|}
\hline$\#$ & Land Classes & Definition \\
\hline 1 & $\mathrm{TDF}$ & $\begin{array}{l}\text { Stands of tree species typical of the seasonally dry } \\
\text { tropical forest biome. }\end{array}$ \\
\hline 2 & Cultivated & $\begin{array}{l}\text { Areas under cultivation, cleared for agriculture, or } \\
\text { cultivated during most recent planting season. }\end{array}$ \\
\hline 3 & Pasture & $\begin{array}{l}\text { Areas cleared for cattle grazing with or without } \\
\text { planted pasture grasses. }\end{array}$ \\
\hline 4 & Agroforestry & $\begin{array}{l}\text { Stands of TDF that have been under planted with } \\
\text { coffee plants; full to moderate canopy. }\end{array}$ \\
\hline 5 & Pine Forest & Stands of natural or plantation pine. \\
\hline 6 & Brush & Fallow areas left to regenerate to brush and shrubs. \\
\hline 7 & Cloud & Cloud cover obscuring imagery. \\
\hline 8 & Cloud Shadow & Cloud shadows obscuring imagery. \\
\hline
\end{tabular}

Note: Appendix B contains photographs representative of land classes 1-6.

\section{Digital Change Detection}

To quantify the changes detected in LULC in the municipality of Cinco Pinos, I used the Matrix Union tool in IMAGINE to create a single image containing classes indicative of how the LULC changed over time. The Matrix Union tool is a postclassification comparison change detection algorithm. Because post-classification comparison change detection is relatively simple to understand, it is utilized more often than other quantitative change detection methods (Jensen 2005). Utilizing this approach, two classified images are compared pixel-by-pixel (Jensen 2005). One caveat is that although this type of classification provides detailed 'from-to' change class information, accuracy is dependent on the accuracy of the two individual date classification inputs (Rutchey and Velcheck 1994; Augenstein 1991). 
To highlight the conversion of TDF to agricultural uses (cultivated, pasture, or brush) and vice-versa, only those specific classes were mapped in the change detection for simple interpretability. Areas of TDF converted to agricultural uses are displayed in red, and areas of agriculture returned to TDF are displayed in green (Figure 3.4).

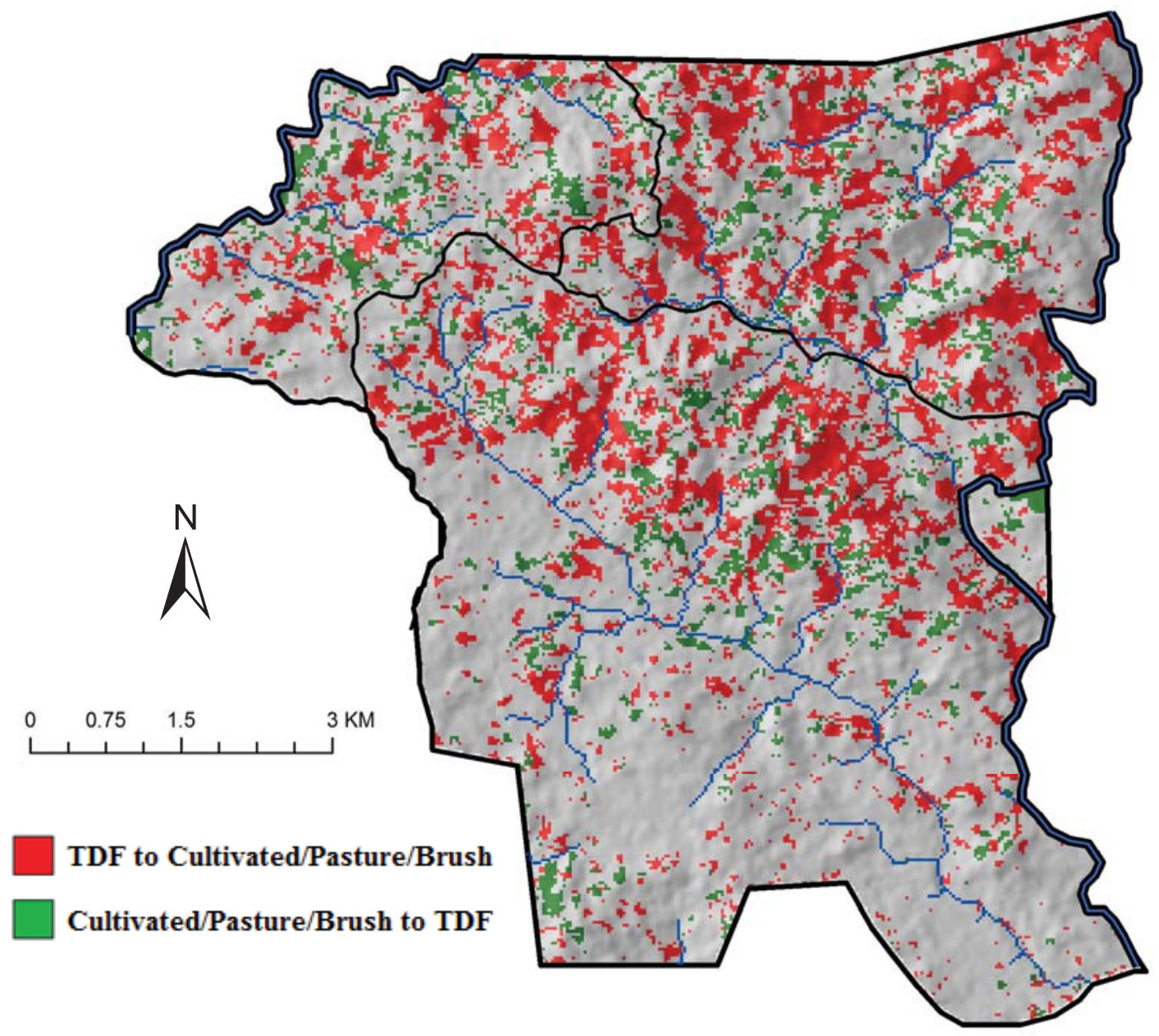

Figure 3.4. LULCC detection map merged into two general change classes for Cinco Pinos from 1985-1990. 


\section{Accuracy Assessment}

Using the 2011 supervised classification raster; I conducted an accuracy assessment using the IMAGINE Accuracy Assessment tool to represent commission and omission errors in addition to the accuracy of the supervised classification (Zeledon and Kelly 2009). An error matrix effectively characterizes map accuracy by representing individual accuracies of each land class as well as the commission and omission errors in the supervised classification (Congalton and Green 2009). Commission errors are the inclusion of land classes into a category to which it does not actually belong. Omission errors are the exclusion of land classes from the category to which it actually does belong. As such, every error is an omission from the correct category and a commission to an incorrect category.

The error matrix is also used to calculate overall accuracy, producer's accuracy, and user's accuracy (Story and Congalton 1986). Overall accuracy is calculated by dividing the sum of the correctly classified sample units by the total number of sample units in the error matrix. Producer's accuracy is the total number of correct sample units from a specific category (eg. TDF) divided by the total number of TDF sample units as indicated by the column total (Congalton and Green 2009). To calculate the user's accuracy, the total number of correct sample units from a specific category (eg. TDF) is divided by the total number of pixels classified as TDF. The distinction is important because it is possible to have a high producer's accuracy (>85\%) and a low user's accuracy $(<85 \%)$. While the producer's accuracy could indicate a high percentage of 
TDF correctly identified as TDF, the user's accuracy could indicate a low percentage of the areas called TDF on the map to actually be TDF on the ground.

The IMAGINE Accuracy Assessment tool selects random coordinates that are then referenced to a single pixel. A $3 \times 3$ window is placed around that center pixel assigning a land cover value to that location based on the majority land cover pixel for those nine neighborhood pixels. This process eliminates bias in the accuracy assessment that would otherwise occur if the assessment were conducted on a pixel-by-pixel basis.

By determining the overall, producer's, and user's accuracies of the 2011 supervised classification I was able to surmise the overall accuracy of the remaining supervised classifications. 


\section{CHAPTER 4 - RESULTS \& ANALYSIS}

Through digital image processing and GIS analyses, the extent (hectares) of six land classes (TDF, cultivated, pasture, agroforestry, pine forest, and brush) were determined, as well as the percent of LULCC at 4-5 year intervals. The supervised classification maps for 1985, 1990, 1994, 2000, 2007, and 2011 are shown in Figures 4.1-4.6. LULCC in hectares is represented in tables 4.1, 4.3, 4.5, 4.7, 4.9, and 4.11 for 19851990, 1990-1994, 1994-2000, 2000-2007, 2007-2011, and 1985-2011, respectively, with net losses shown in red. Digital change detection maps for LULCC are shown in Figures 4.7-4.12 for the same time series. The percent of LULCC is displayed in tables 4.2, 4.4, 4.6, 4.8, 4.10, and 4.12.

The classification accuracy assessment report indicated an overall classification accuracy of $87.38 \%$. The result of the Kappa analysis was a KHAT $\left(\mathrm{K}^{\wedge}\right)$ statistic of 0.8250 that falls within the acceptable range of accuracy for remotely sensed data. A Kappa analysis is a discrete multivariate technique used in the accuracy assessment to identify significant differences between error matrices (Bishop et al. 1975). The KHAT statistic functions similar to the CHI square analysis. It is a measure of agreement based on the difference between the actual agreement in the error matrix and a chance agreement shown by the row and column totals. 


\subsection{Results \& Analysis of Supervised Classifications}

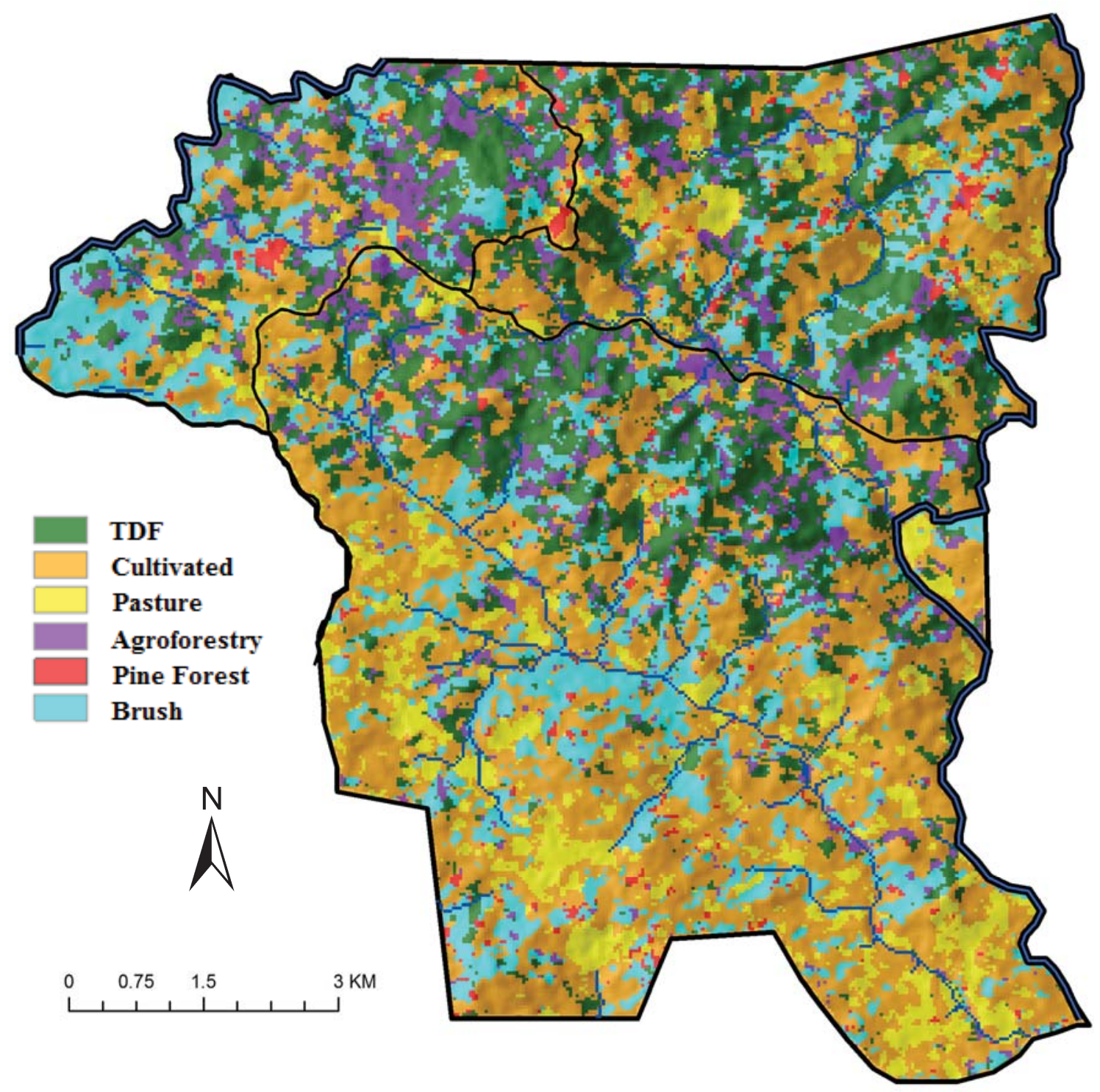

Figure 4.1. Supervised classification result of Cinco Pinos LULCC for 1985. 


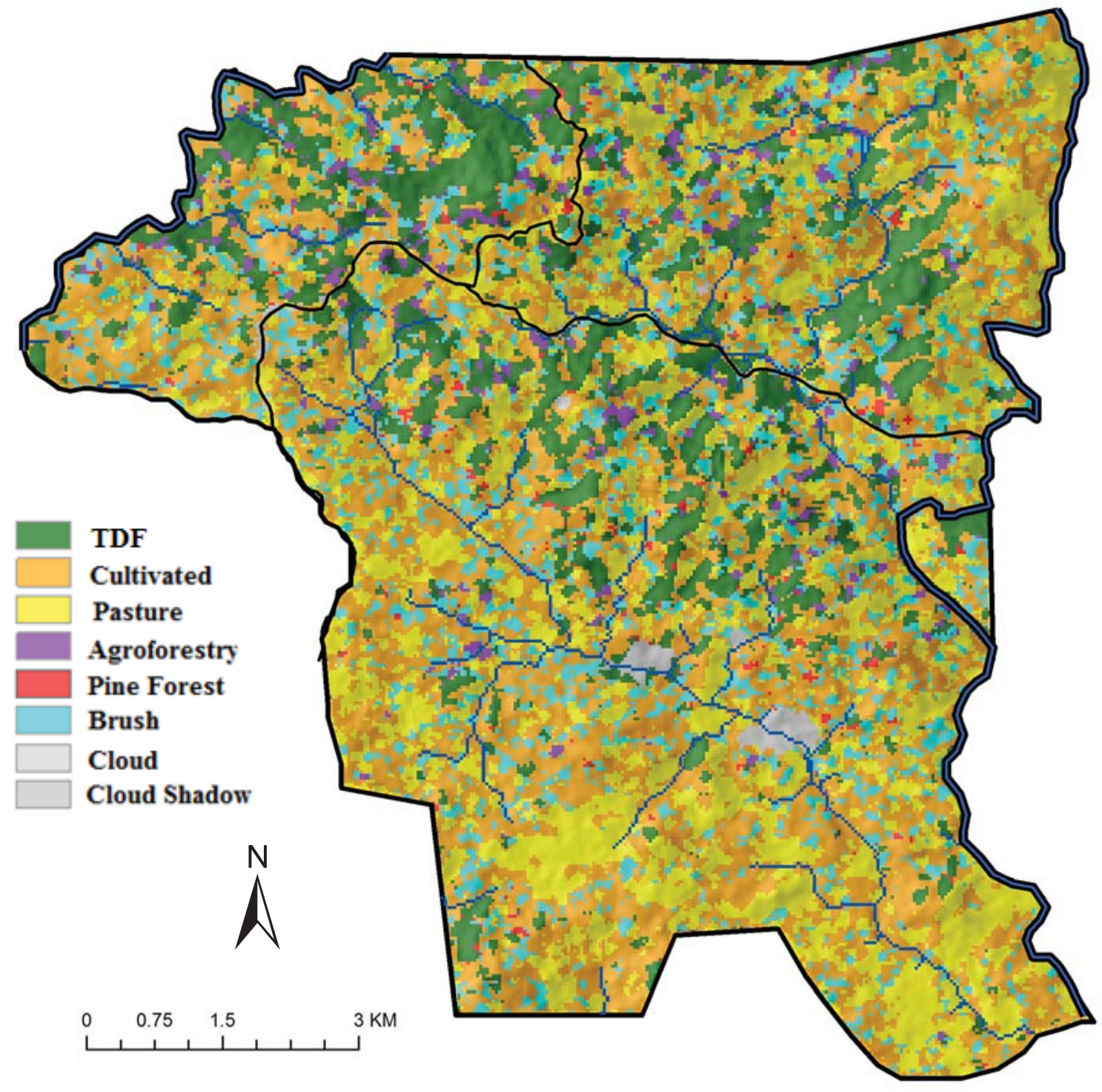

Figure 4.2. Supervised classification result of Cinco Pinos LULCC for 1990. 


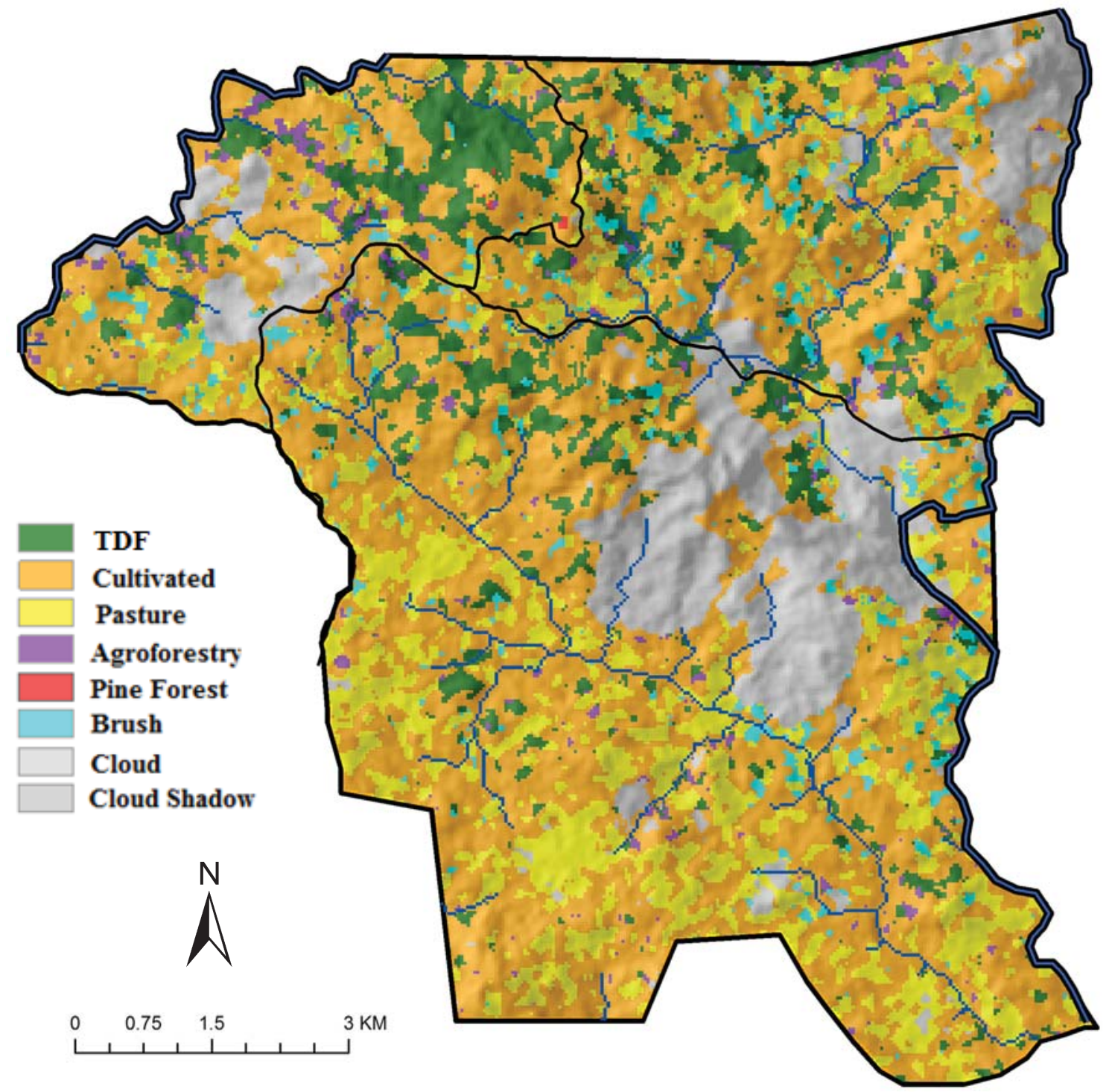

Figure 4.3. Supervised classification result of Cinco Pinos LULCC for 1994. 


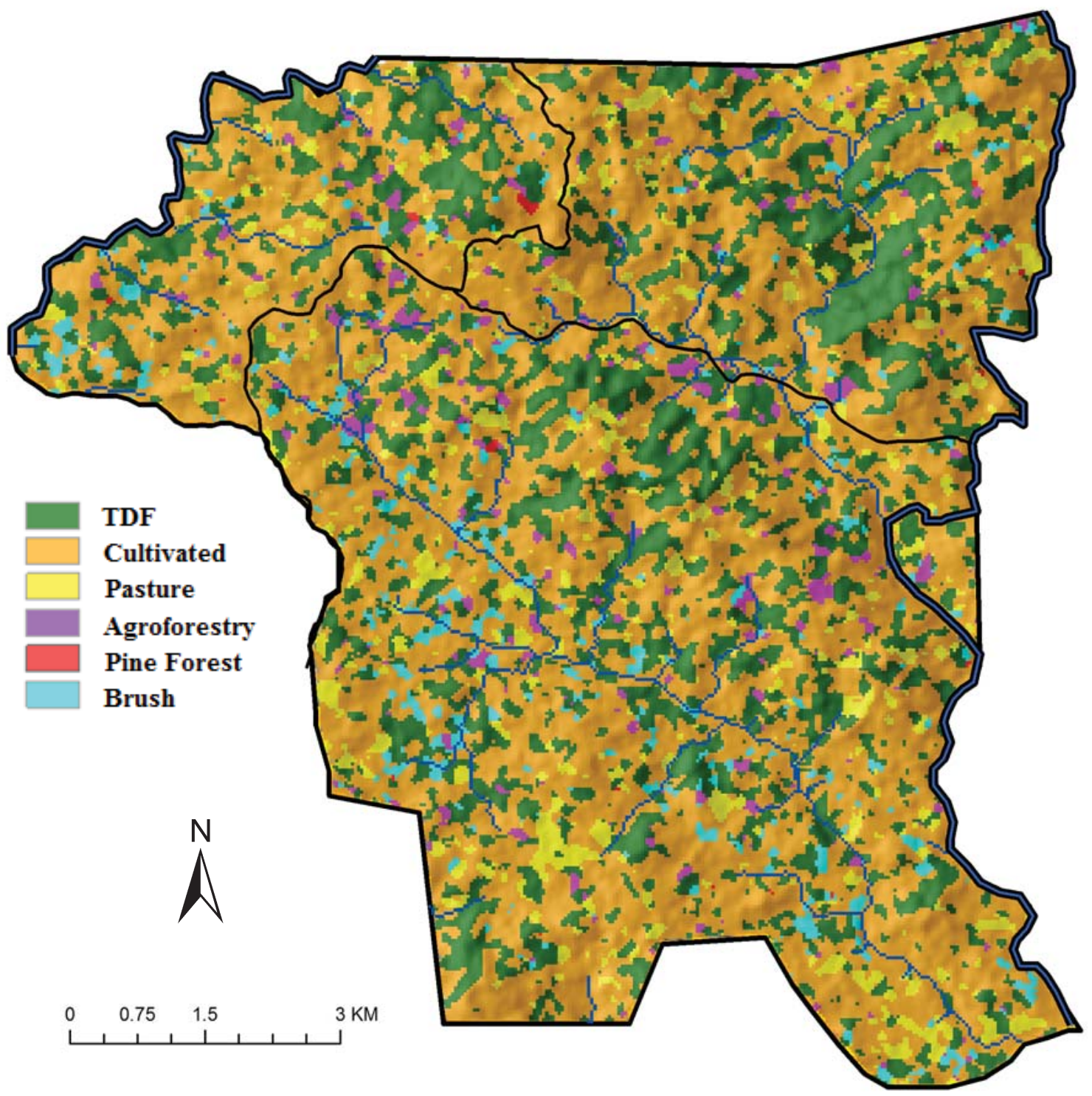

Figure 4.4. Supervised classification result of Cinco Pinos LULCC for 2000. 


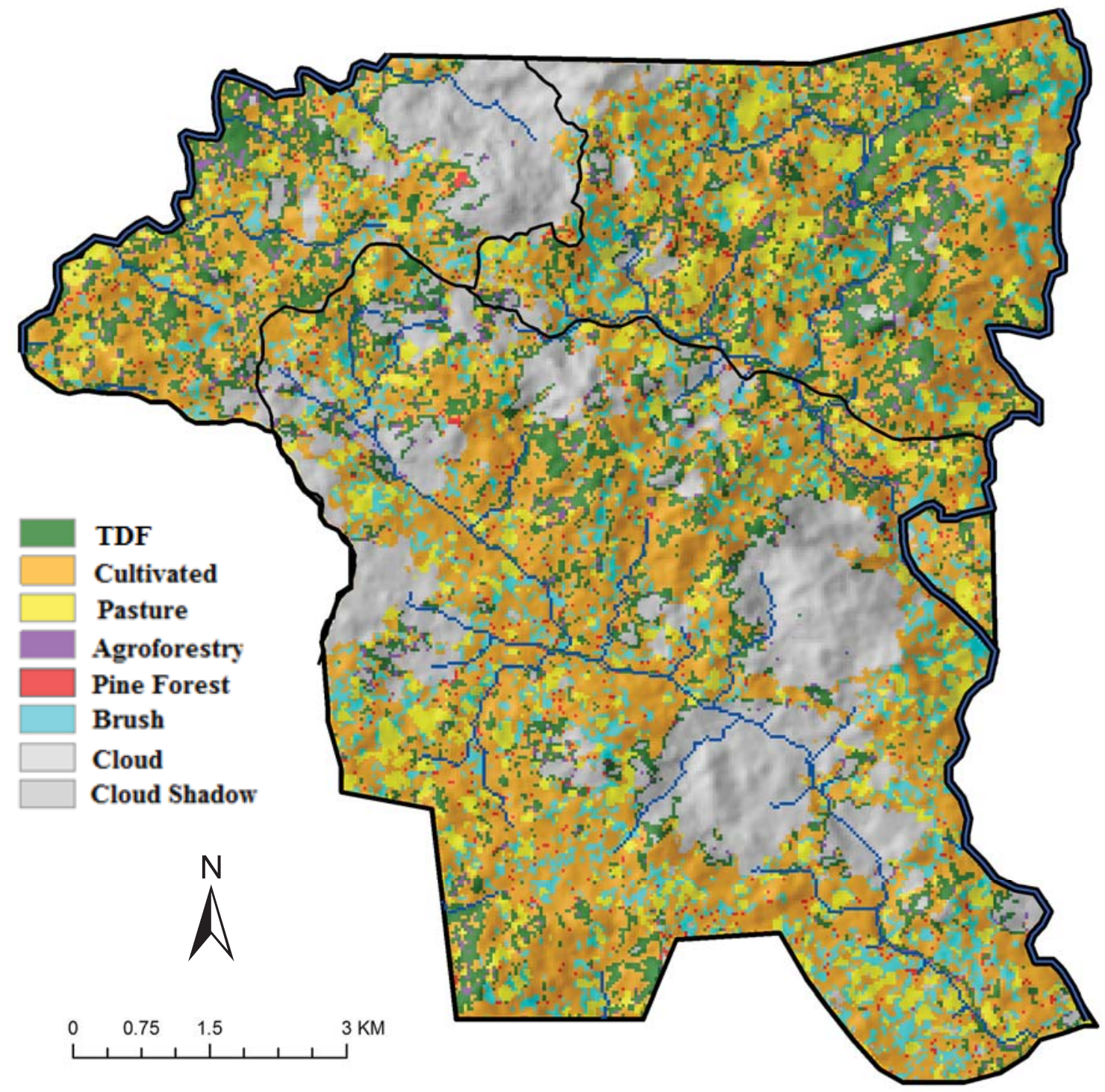

Figure 4.5. Supervised classification result of Cinco Pinos LULCC for 2007. 


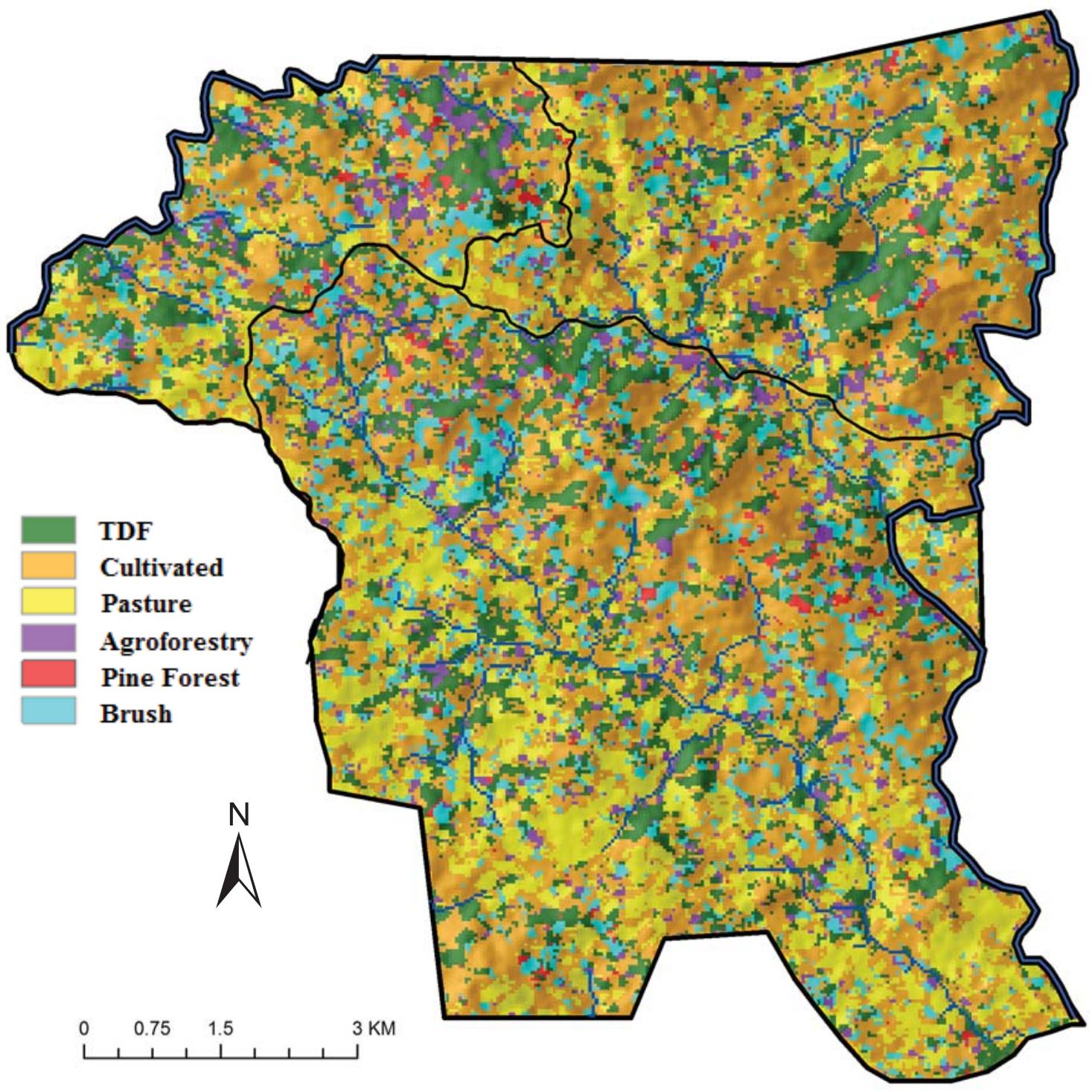

Figure 4.6. Supervised classification result of Cinco Pinos LULCC for 2011. 


\subsection{Results \& Analysis of Digital Change Detections}

During the five-year period from 1985 to $1990,346.05$ ha of TDF were converted to alternate land uses (Table 4.1). The majority of the TDF conversion was to cultivation and pasture, respectively. The net gain of cultivated areas was 73.26 ha and 1026.00 ha for pasture. Areas used for agroforestry declined by 372.42 ha. Total hectares of pine forest were reduced by 57.51 ha. Brush declined by 323.28 ha overall despite 357.57 ha of cultivation converted to brush. Net change for each land class was calculated by subtracting the sum of the class column from the amount of that land class (ha) present in 1985 (sum of the land class row). Net losses are shown in red. Table 4.2 gives the values for the percent of LULCC of each land class from 1985-1990.

Table 4.1. LULCC in hectares (ha) in Cinco Pinos 1985-1990. 1990

\begin{tabular}{|c|c|c|c|c|c|c|c|}
\hline & 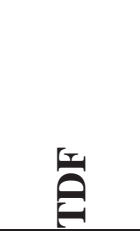 & U & 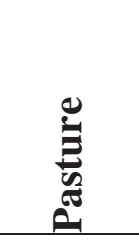 & 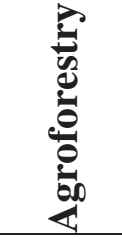 & 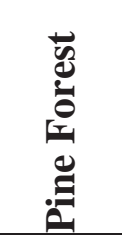 & 矛 & 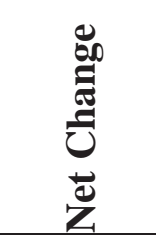 \\
\hline TDF & 443.16 & 410.76 & 358.38 & 42.66 & 7.20 & 168.93 & $(346.05)$ \\
\hline Cultivated & 135.18 & 1187.19 & 767.25 & 37.26 & 11.97 & 357.57 & 73.26 \\
\hline Pasture & 6.03 & 174.15 & 345.69 & 3.06 & 0.90 & 34.56 & 1026.00 \\
\hline Agro & 205.65 & 163.89 & 36.54 & 59.04 & 5.13 & 72.09 & $(372.42)$ \\
\hline Pine For & 29.88 & 52.83 & 5.49 & 1.80 & 3.42 & 12.42 & $(57.51)$ \\
\hline Brush & 265.14 & 580.86 & 77.04 & 26.10 & 19.71 & 190.71 & $(323.28)$ \\
\hline
\end{tabular}




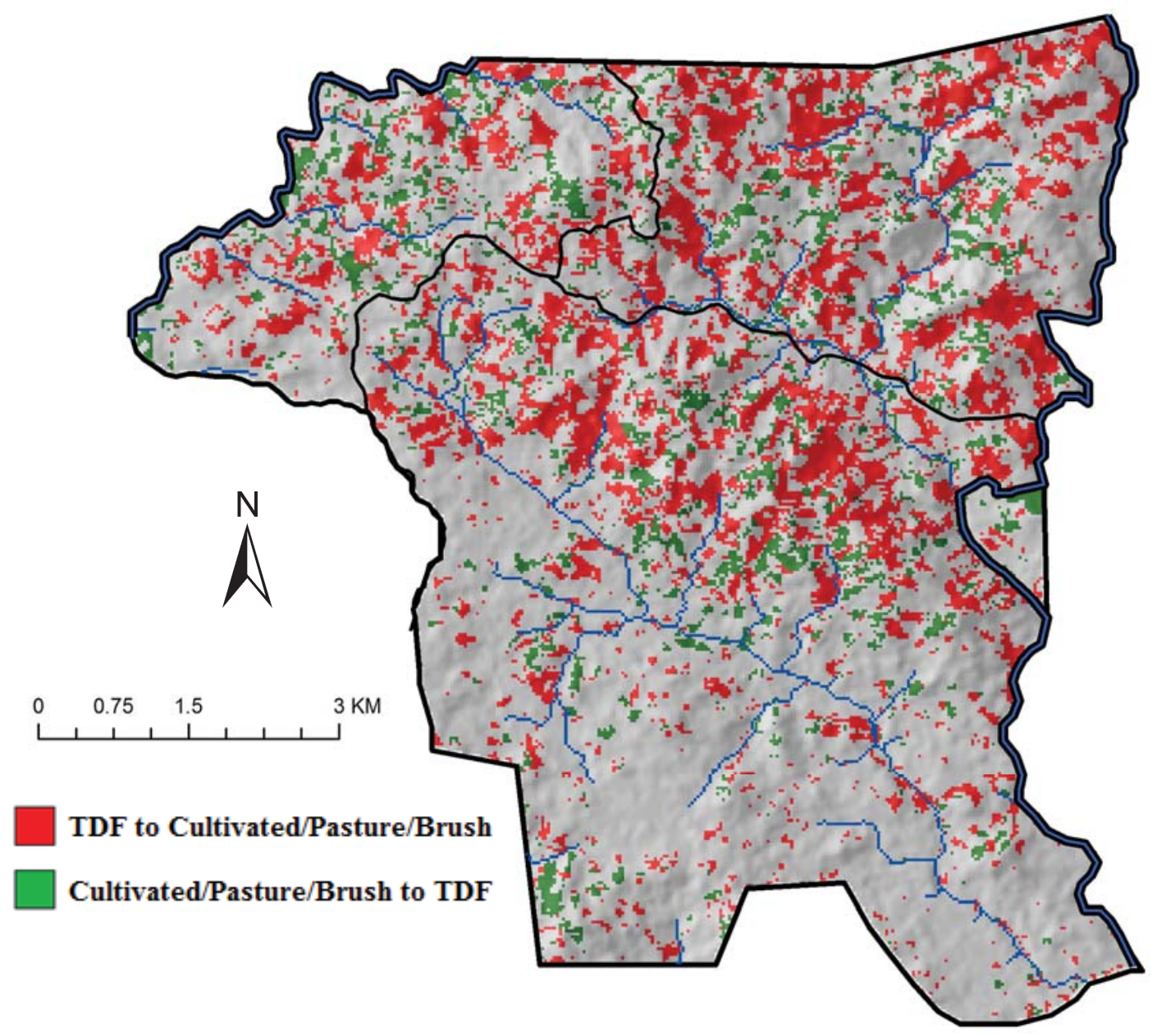

Figure 4.7. LULC change detection map merged into two general change classes for Cinco Pinos 1985-1990.

Table 4.2. Percent of LULCC in Cinco Pinos 1985-1990.

\begin{tabular}{|c|c|c|c|c|c|c|}
\hline \multicolumn{7}{|c|}{1990} \\
\hline & 香 & 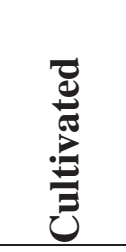 & 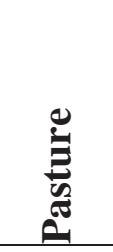 & 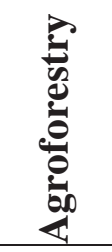 & 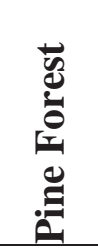 & 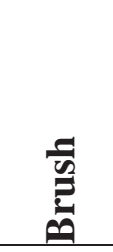 \\
\hline TDF & 30.86 & 28.60 & 24.96 & 2.97 & 0.50 & 11.76 \\
\hline Cultivated & 5.35 & 47.03 & 30.39 & 1.48 & 0.47 & 14.16 \\
\hline Pasture & 1.05 & 30.32 & 60.18 & 0.53 & 0.16 & 6.02 \\
\hline Agroforestry & 37.82 & 30.14 & 6.72 & 10.86 & 0.94 & 13.26 \\
\hline Pine Forest & 28.02 & 49.54 & 5.15 & 1.69 & 3.21 & 11.65 \\
\hline Brush & 22.63 & 49.57 & 6.57 & 2.23 & 1.68 & 16.27 \\
\hline
\end{tabular}


During the four-year period from 1990 to $1994,204.48$ ha of TDF were converted to alternate land uses (Table 4.3). The majority of the TDF conversion was to cultivated areas. Fewer hectares of TDF were converted to pasture from 1990 to 1994 (16.56 ha) compared to 1985 to 1990 (358.38 ha). The net gain of cultivated areas was 950.85 ha with 1553.49 ha remaining cultivated. Pasture declined by 176.22 ha. Areas used for agroforestry declined by 38.70 ha. Total ha of pine forest were reduced by 35.37 . Brush declined by 496.08 ha. Table 4.4 gives the values for the percent of LULCC of each land class from 1990 to 1994.

Table 4.3. LULCC in hectares (ha) in Cinco Pinos 1990-1994. 1994

\begin{tabular}{|c|c|c|c|c|c|c|c|}
\hline & 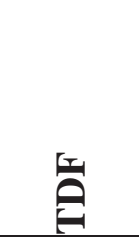 & 营 & 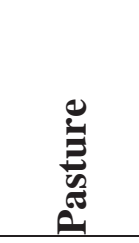 & 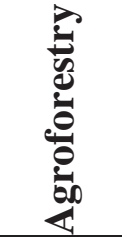 & 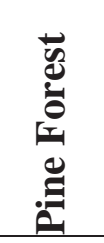 & 昰 & 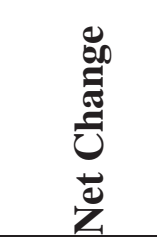 \\
\hline TDF & 381.60 & 463.14 & 16.56 & 43.29 & 1.89 & 8.46 & $(204.48)$ \\
\hline Cultivated & 150.39 & 1553.49 & 397.80 & 38.34 & 0.00 & 81.45 & 950.85 \\
\hline Pasture & 54.09 & 555.03 & 653.85 & 4.14 & 0.00 & 95.04 & $(176.22)$ \\
\hline Agroforestry & 55.17 & 73.08 & 5.49 & 10.26 & 0.00 & 1.80 & (38.70) \\
\hline Pine Forest & 4.86 & 30.06 & 0.54 & 1.17 & 0.00 & 0.63 & (35.37) \\
\hline Brush & 64.35 & 497.52 & 111.69 & 9.90 & 0.00 & 34.92 & $(496.08)$ \\
\hline
\end{tabular}




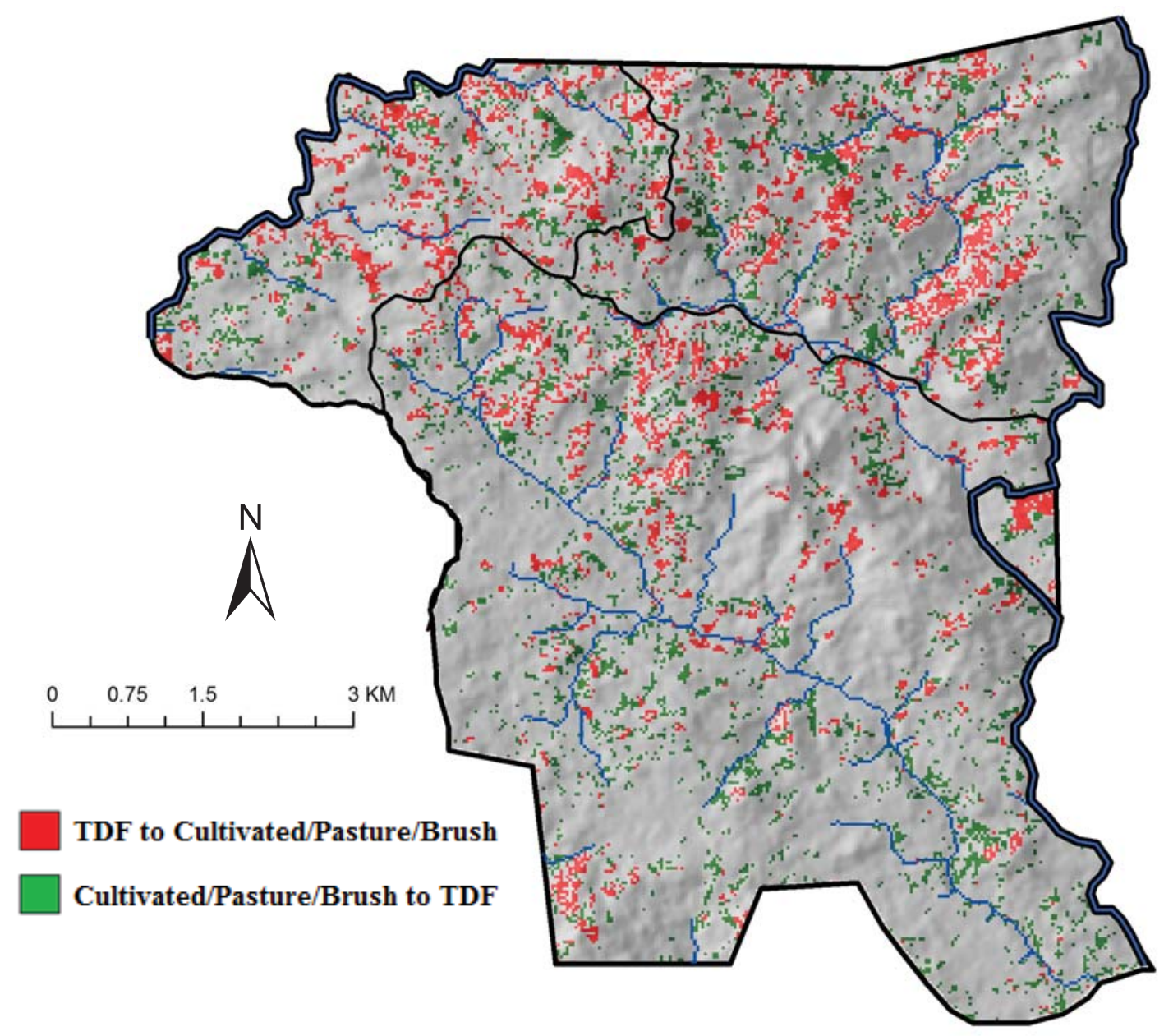

Figure 4.8. LULC change detection map merged into two general change classes for Cinco Pinos 1990-1994.

Table 4.4. Percent of LULCC in Cinco Pinos 1990-1994. 1994

\begin{tabular}{|c|c|c|c|c|c|c|}
\hline & 皆 & 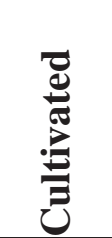 & 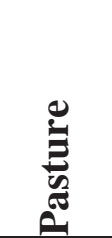 & 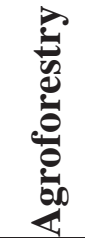 & 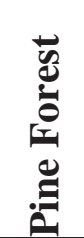 & $\stackrel{\frac{\pi}{n}}{2}$ \\
\hline TDF & 35.20 & 42.73 & 1.53 & 3.99 & 0.17 & 0.78 \\
\hline Cultivated & 5.85 & 60.46 & 15.48 & 1.49 & 0.00 & 3.17 \\
\hline Pasture & 3.40 & 34.90 & 41.12 & 0.26 & 0.00 & 5.98 \\
\hline Agroforestry & 32.47 & 43.01 & 3.23 & 6.04 & 0.00 & 1.06 \\
\hline Pine Forest & 10.06 & 62.20 & 1.12 & 2.42 & 0.00 & 1.30 \\
\hline Brush & 7.70 & 59.50 & 13.36 & 1.18 & 0.00 & 4.18 \\
\hline
\end{tabular}


During the six-year period from 1994 to $2000,779.50$ ha of land returned to TDF (Table 4.5). Cultivated areas increased by 35.91 ha, while pasture declined significantly by 818.90 ha. Areas used for agroforestry increased by 32.67 ha. Total ha of pine forest were increased by 5.31. Brush declined by 34.47 ha. Table 4.6 presents the values for the percent of LULCC of each land class from 1994 to 2000.

Table 4.5. LULCC in hectares (ha) in Cinco Pinos 1994-2000. 2000

\begin{tabular}{|c|c|c|c|c|c|c|c|}
\hline & 恧 & 苞 & 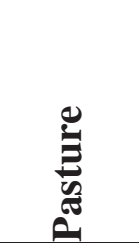 & 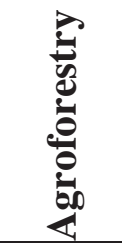 & 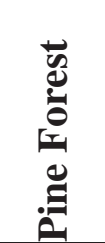 & $\overline{\underline{n}}$ & 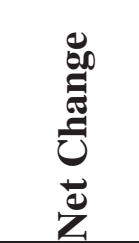 \\
\hline TDF & 313.92 & 323.64 & 17.82 & 42.48 & 0.36 & 12.15 & 779.50 \\
\hline Cultivated & 842.76 & 1968.57 & 177.48 & 77.58 & 4.77 & 131.67 & 35.91 \\
\hline Pasture & 233.37 & 749.88 & 162.36 & 8.28 & 1.08 & 38.61 & (818.9) \\
\hline Agroforestry & 36.18 & 56.43 & 3.78 & 7.20 & 0.18 & 2.61 & 32.67 \\
\hline Pine Forest & 0.81 & 1.08 & 0.00 & 0.00 & 0.00 & 0.00 & 5.31 \\
\hline Brush & 62.82 & 139.14 & 13.23 & 3.51 & 0.81 & 8.73 & (34.47) \\
\hline
\end{tabular}




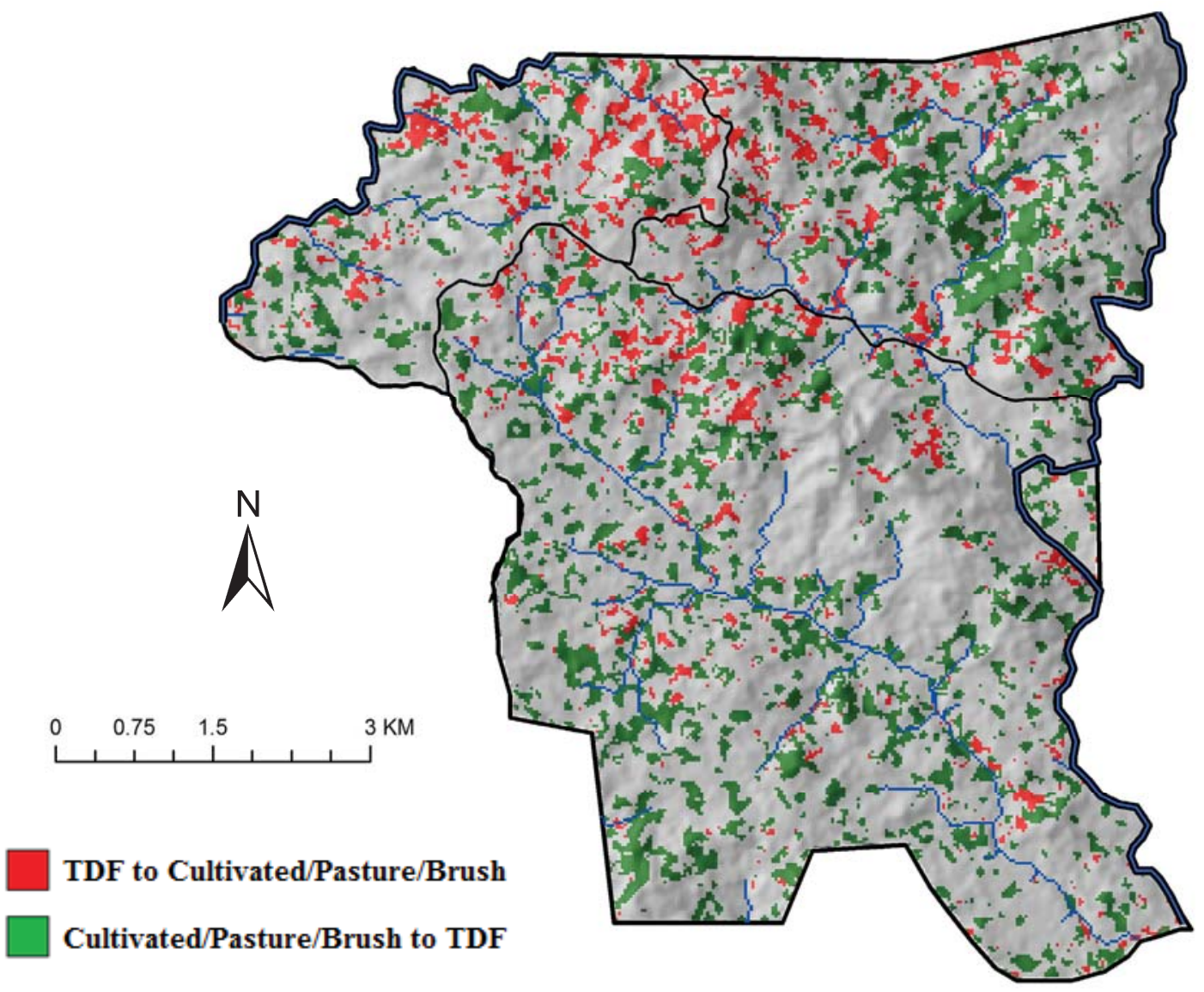

Figure 4.9. LULCC change detection map merged into two general change classes for Cinco Pinos 1994-2000.

Table 4.6. Percent of LULCC in Cinco Pinos 1994-2000. 2000

\begin{tabular}{|c|c|c|c|c|c|c|}
\hline & 香 & U & 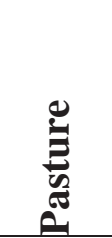 & 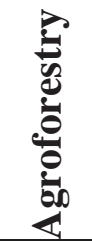 & 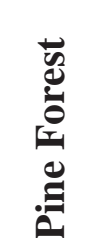 & $\stackrel{\bar{n}}{\overline{2}}$ \\
\hline TDF & 44.19 & 45.56 & 2.51 & 5.98 & 0.05 & 1.71 \\
\hline Cultivated & 26.31 & 61.46 & 5.54 & 2.42 & 0.15 & 4.11 \\
\hline Pasture & 19.55 & 62.83 & 13.60 & 0.69 & 0.09 & 3.23 \\
\hline Agroforestry & 34.01 & 53.05 & 3.55 & 6.77 & 0.17 & 2.45 \\
\hline Pine Forest & 42.86 & 57.14 & 0.00 & 0.00 & 0.00 & 0.00 \\
\hline Brush & 27.52 & 60.96 & 5.80 & 1.54 & 0.35 & 3.82 \\
\hline
\end{tabular}


During the seven-year interval from 2000 to 2007, a 535.23 ha decline in TDF cover was observed (Table 4.7). Cultivated and pasture areas increased by 77.31 ha and 281.97 ha, respectively. Areas utilized for agroforestry declined by 94.14 ha. In pine forests, we saw a slight increase with 0.27 ha. Brush cover increased by 269.82 ha. Table 4.8 provides the values for the percent of LULCC of each land class from 2000 to 2007.

Table 4.7. LULCC in hectares (ha) in Cinco Pinos 2000-2007. 2007

\begin{tabular}{|c|c|c|c|c|c|c|c|}
\hline & 告 & 莺 & 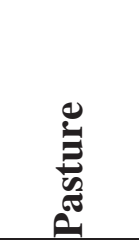 & 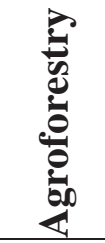 & 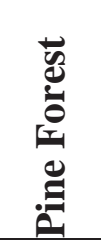 & t: & 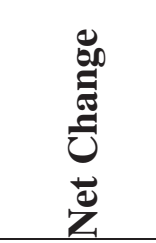 \\
\hline TDF & 354.87 & 774.45 & 149.94 & 9.54 & 2.52 & 85.05 & $(535.23)$ \\
\hline Cultivated & 425.97 & 1902.96 & 397.44 & 16.11 & 3.33 & 279.09 & 77.31 \\
\hline Pasture & 23.76 & 214.83 & 60.75 & 0.72 & 0.09 & 58.32 & 281.97 \\
\hline Agroforestry & 20.16 & 88.38 & 9.54 & 0.27 & 0.00 & 3.06 & $(94.14)$ \\
\hline Pine Forest & 0.00 & 4.41 & 0.54 & 0.00 & 0.00 & 0.72 & 0.27 \\
\hline Brush & 16.38 & 117.18 & 22.23 & 0.63 & 0.00 & 10.26 & 269.82 \\
\hline
\end{tabular}




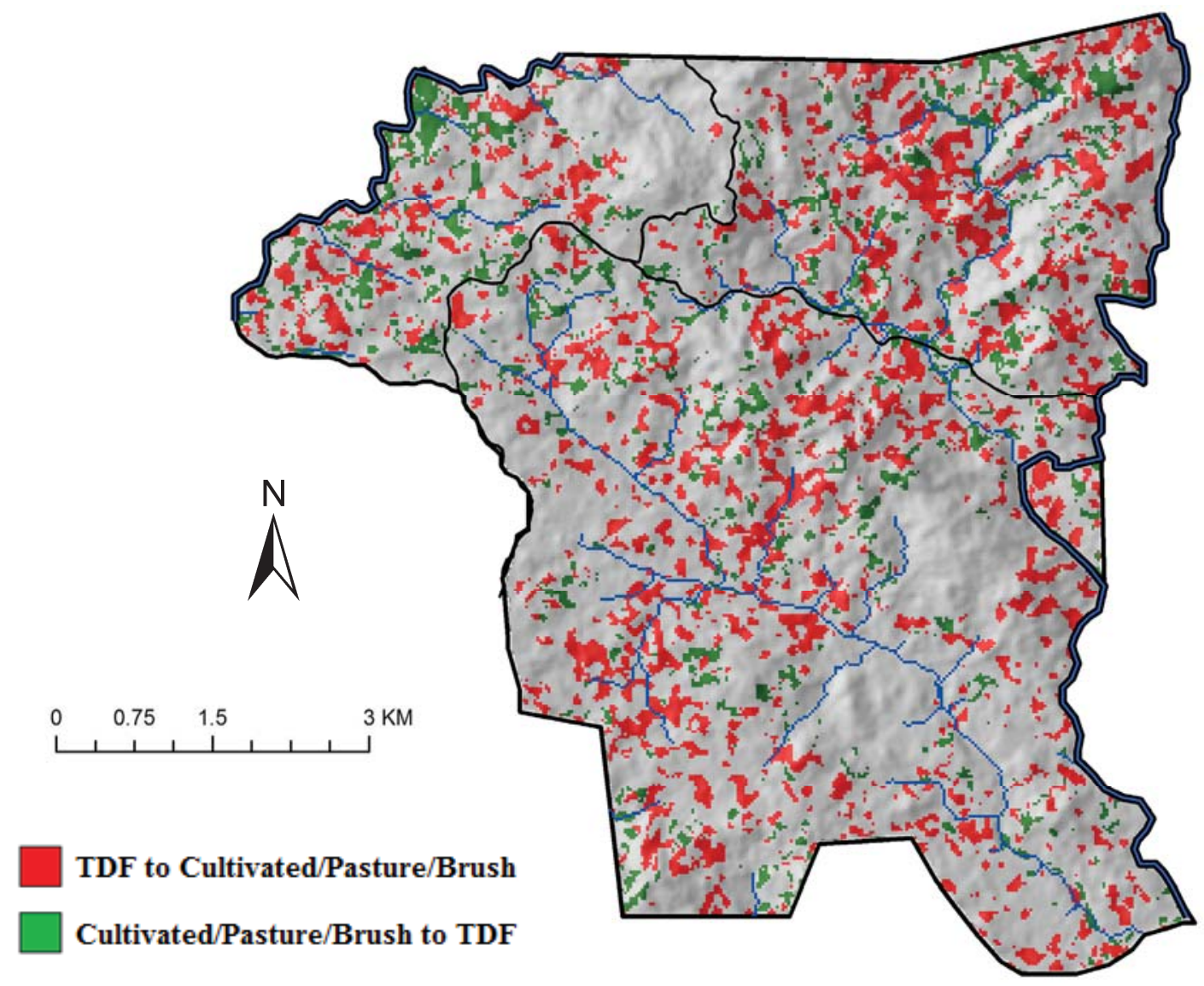

Figure 4.10. LULCC change detection map merged into two general change classes for Cinco Pinos 2000-2007.

Table 4.8. Percent of LULCC in Cinco Pinos 2000-2007. 2007

\begin{tabular}{|c|c|c|c|c|c|c|}
\hline & 乒 & 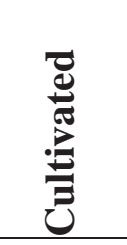 & 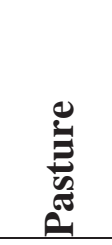 & 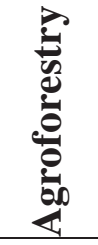 & 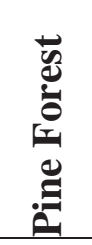 & $\stackrel{\tilde{Q}}{\mathscr{E}}$ \\
\hline TDF & 20.10 & 43.87 & 8.49 & 0.54 & 0.14 & 4.82 \\
\hline Cultivated & 11.29 & 50.44 & 10.54 & 0.43 & 0.09 & 7.40 \\
\hline Pasture & 5.58 & 50.50 & 14.28 & 0.17 & 0.02 & 13.71 \\
\hline Agroforestry & 12.27 & 53.81 & 5.81 & 0.16 & 0.00 & 1.86 \\
\hline Pine Forest & 0.00 & 55.06 & 6.74 & 0.00 & 0.00 & 8.99 \\
\hline Brush & 7.73 & 55.29 & 10.49 & 0.30 & 0.00 & 4.84 \\
\hline
\end{tabular}


During the four-year period from 2007 to 2011, TDF increased by 119.25 ha (Table 4.9). The net loss of the cultivated class was 860.76 ha while areas designated for pasture increased by 341.91 ha. Areas used for agroforestry increased by 248.49 ha. Total ha of pine forest increased by 40.86. Brush also increased by 110.25 ha. Table 4.10 presents the values for the percent of LULCC of each land class from 2007 to 2011.

Table 4.9. LULCC in hectares (ha) in Cinco Pinos 2007-2011. 2011

\begin{tabular}{|c|c|c|c|c|c|c|}
\hline 留 & 总 & 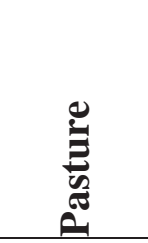 & 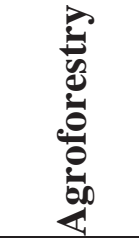 & 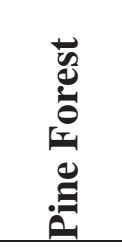 & $\frac{\tilde{n}}{\bar{n}}$ & 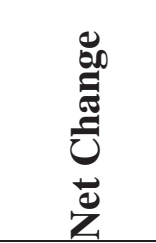 \\
\hline 306.27 & 331.92 & 74.16 & 48.69 & 15.93 & 63.00 & 119.25 \\
\hline 550.89 & 1363.86 & 587.07 & 182.43 & 24.93 & 395.64 & $(860.76)$ \\
\hline 54.90 & 324.99 & 180.81 & 26.46 & 3.24 & 50.13 & 341.91 \\
\hline 7.02 & 13.59 & 3.51 & 0.63 & 0.27 & 1.89 & 248.49 \\
\hline 1.53 & 1.71 & 0.18 & 0.27 & 1.44 & 0.72 & 40.86 \\
\hline 38.61 & 207.99 & 136.71 & 16.92 & 0.90 & 36.63 & 110.25 \\
\hline
\end{tabular}




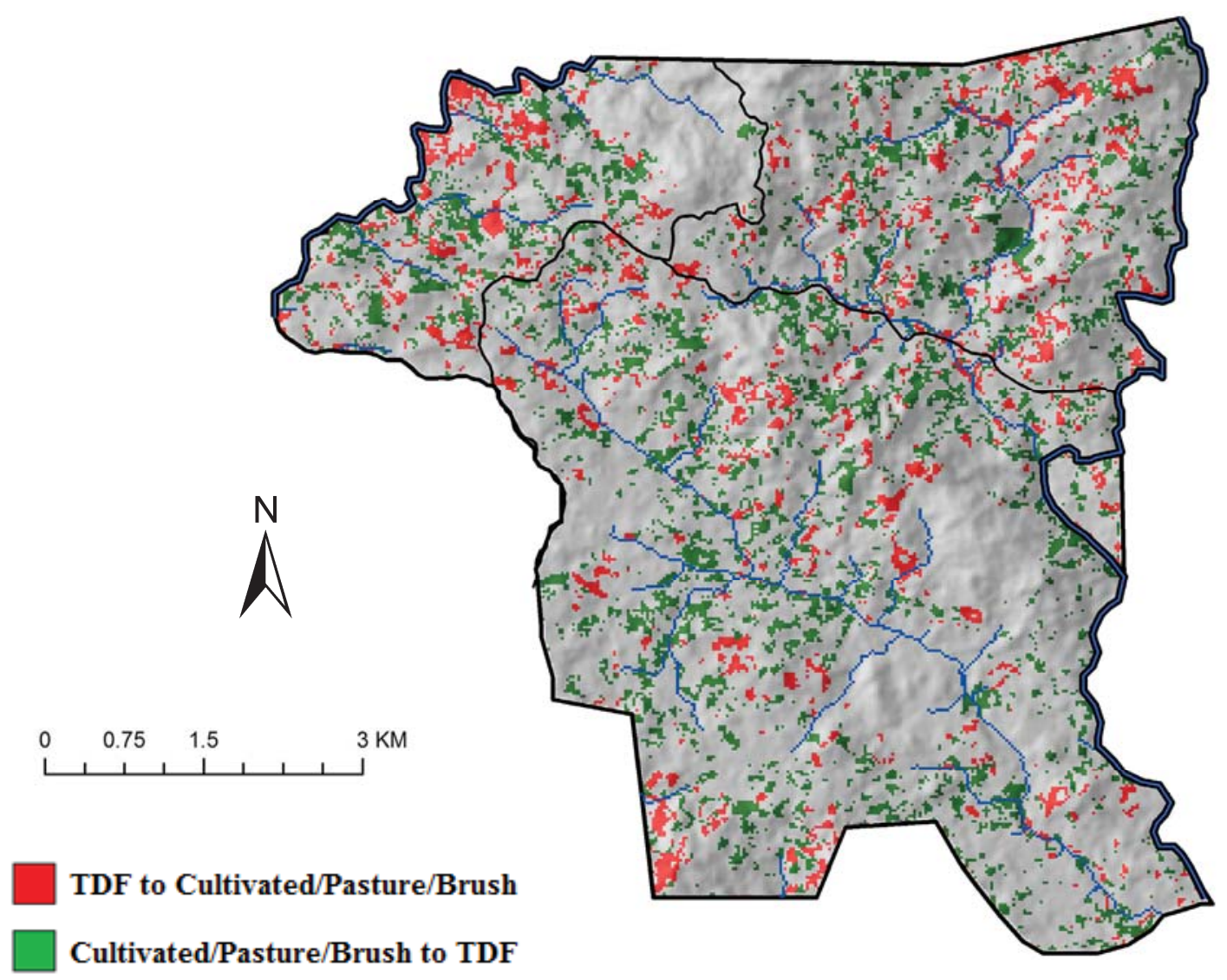

Figure 4.11. LULC change detection map merged into two general change classes for Cinco Pinos for 2007-2011.

Table 4.10. Percent of LULCC in Cinco Pinos 2007-2011. 2011

\begin{tabular}{|c|c|c|c|c|c|c|}
\hline & 乒 & 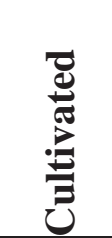 & 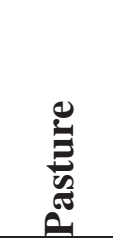 & 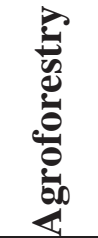 & 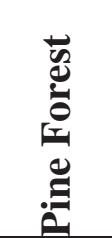 & 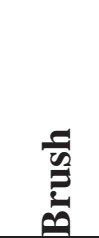 \\
\hline TDF & 36.46 & 39.52 & 8.83 & 5.80 & 1.90 & 7.50 \\
\hline Cultivated & 17.74 & 43.93 & 18.91 & 5.88 & 0.80 & 12.74 \\
\hline Pasture & 8.57 & 50.74 & 28.23 & 4.13 & 0.51 & 7.83 \\
\hline Agroforestry & 26.09 & 50.50 & 13.04 & 2.34 & 1.00 & 7.02 \\
\hline Pine Forest & 26.15 & 29.23 & 3.08 & 4.62 & 24.62 & 12.31 \\
\hline Brush & 8.82 & 47.51 & 31.23 & 3.87 & 0.21 & 8.37 \\
\hline
\end{tabular}


At the end of the 26-year period from 1985 to 2011, 210.51 ha of TDF had been converted to other land uses (Table 4.11). Areas of cultivation increased slightly more with 261.45 ha. Pasture increased by nearly $110 \%$ with a net gain of 632.52 ha. Both agroforestry areas and pine forests declined by 173.88 ha and 34.11 ha, respectively. Brush declined by 475.47 ha. Table 4.12 displays the values for the percent of LULCC of each land class from 1985-2011.

Table 4.11. LULCC in Hectares (ha) in Cinco Pinos 1985-2011. 2011

\begin{tabular}{|c|c|c|c|c|c|c|c|}
\hline & 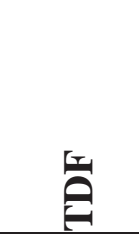 & 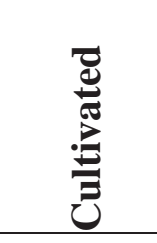 & 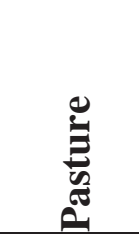 & 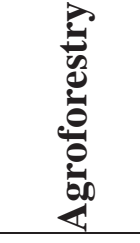 & 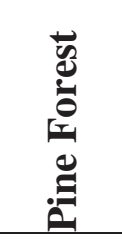 & 昰 & 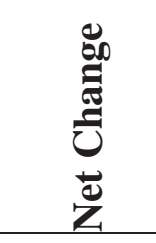 \\
\hline TDF & 387.36 & 675.90 & 110.25 & 83.25 & 19.98 & 157.41 & $(210.51)$ \\
\hline Cultivated & 308.16 & 1204.92 & 593.73 & 117.00 & 14.40 & 286.02 & 261.45 \\
\hline Pasture & 32.85 & 209.61 & 258.03 & 20.70 & 0.90 & 51.75 & 632.52 \\
\hline Agroforestry & 119.43 & 214.47 & 36.90 & 77.04 & 19.35 & 76.86 & (173.88) \\
\hline Pine Forest & 29.07 & 53.64 & 12.69 & 4.14 & 1.71 & 5.49 & (34.11) \\
\hline Brush & 346.77 & 427.14 & 194.76 & 68.04 & 16.29 & 117.09 & (475.47) \\
\hline
\end{tabular}




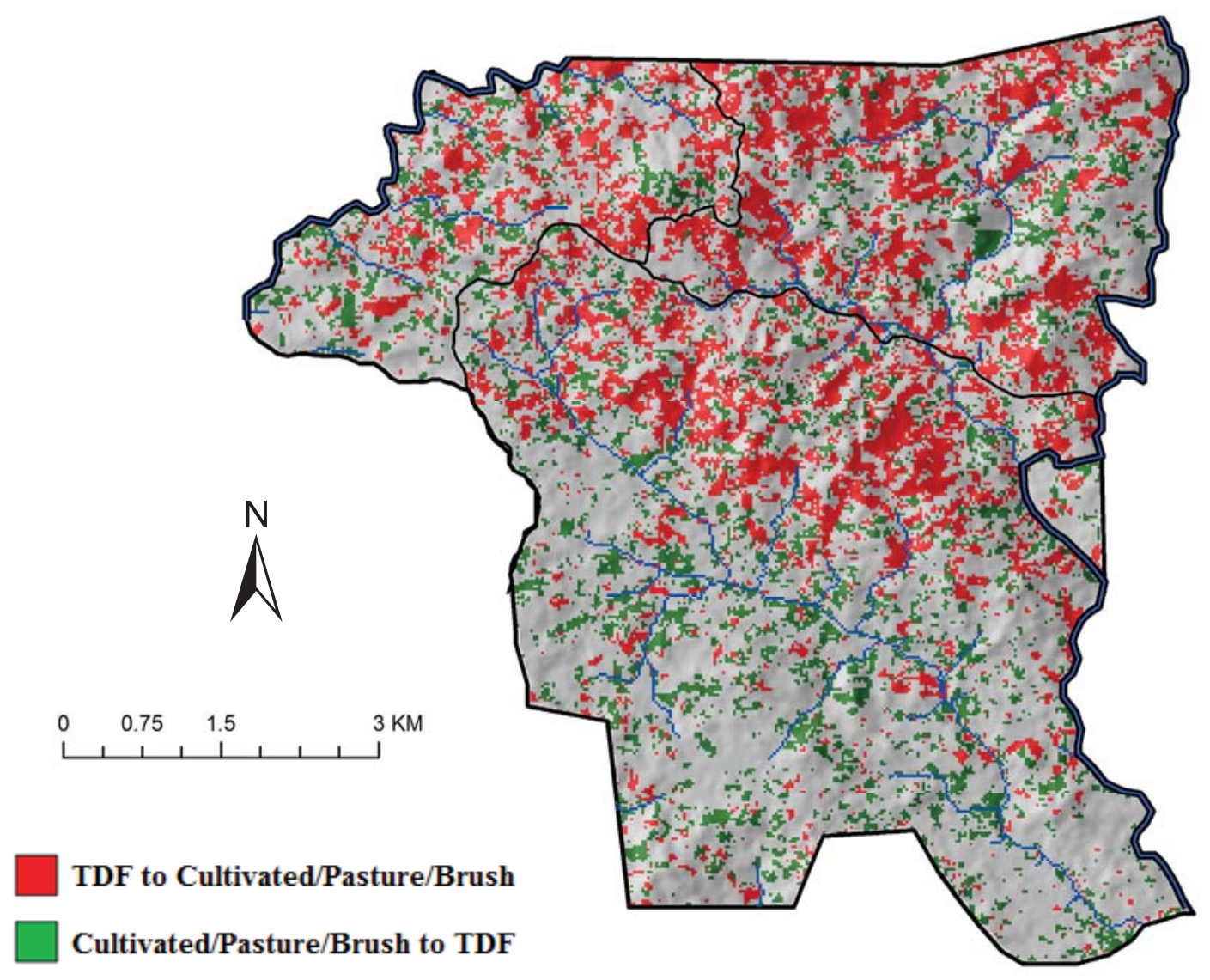

Figure 4.12. LULC change detection map merged into two general change classes for Cinco Pinos for 1985-2011.

Table 4.12. Percent of LULCC in Cinco Pinos 1985-2011. 2011

\begin{tabular}{|c|c|c|c|c|c|c|}
\hline & 鬲 & 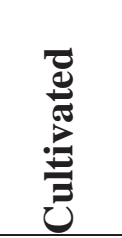 & 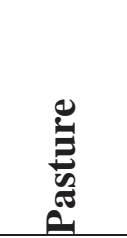 & 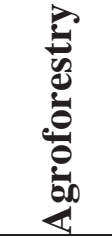 & 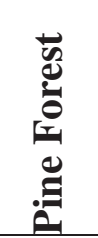 & $\stackrel{n}{\varrho}$ \\
\hline TDF & 27.01 & 47.13 & 7.69 & 5.80 & 1.39 & 10.98 \\
\hline Cultivated & 12.21 & 47.73 & 23.52 & 4.64 & 0.57 & 11.33 \\
\hline Pasture & 5.72 & 36.53 & 44.97 & 3.61 & 0.16 & 9.02 \\
\hline Agroforestry & 21.95 & 39.42 & 6.78 & 14.16 & 3.56 & 14.13 \\
\hline Pine Forest & 27.23 & 50.25 & 11.89 & 3.88 & 1.60 & 5.14 \\
\hline Brush & 29.64 & 36.50 & 16.64 & 5.81 & 1.39 & 10.01 \\
\hline
\end{tabular}




\subsection{Results \& Analysis of Accuracy Assessment}

The results of the classification accuracy assessment indicate an overall accuracy of 87.38\% (Table 4.13). This is an acceptable accuracy given that results $>85 \%$ are acceptable according to the standard first suggested by Anderson (1976), and that now seem to be recognized universally (Congalton and Green 1999).

Table 4.13. Error matrix representing accuracy of supervised classification 2011.

\begin{tabular}{|c|c|c|c|c|c|c|c|}
\hline \multicolumn{8}{|c|}{ Reference Data } \\
\hline & 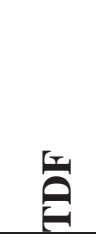 & 胥 & 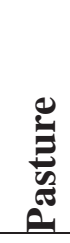 & 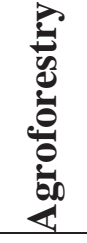 & 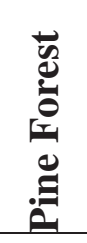 & $\stackrel{\bar{n}}{\bar{D}}$ & 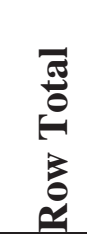 \\
\hline TDF & 90 & 6 & 0 & 0 & 0 & 4 & 100 \\
\hline Cultivated & 7 & 212 & 6 & 0 & 0 & 6 & 231 \\
\hline Pasture & 0 & 8 & 82 & 0 & 0 & 0 & 90 \\
\hline Agroforestry & 4 & 1 & 3 & 16 & 0 & 3 & 27 \\
\hline Pine Forest & 4 & 2 & 0 & 0 & 16 & 6 & 28 \\
\hline Brush & 3 & 3 & 0 & 0 & 0 & 41 & 47 \\
\hline ColumnTotal & 108 & 232 & 91 & 16 & 16 & 60 & 523 \\
\hline
\end{tabular}

OVERALL ACCURACY $=(\mathbf{9 0 + 2 1 2 + 8 2 + 1 6 + 1 6 + 4 1 )} / 523=457 / 523=\mathbf{8 7 . 3 8 \%}$

\section{PRODUCER'S ACCURACY:}

$\mathrm{TDF}=90 / 108=83.33 \%$

Cultivated $=212 / 232=91.38 \%$

Pasture $=82 / 91=90.11 \%$

Agroforestry $=16 / 16=100.00 \%$

Pine Forest $=16 / 16=100.00 \%$

Brush $=41 / 60=68.33 \%$

\section{USERS'S ACCURACY:}

$\mathrm{TDF}=90 / 100=90.00 \%$

Cultivated $=212 / 231=91.77 \%$

Pasture $=82 / 90=91.11 \%$

Agroforestry $=16 / 27=59.26 \%$

Pine Forest $=16 / 28=57.14 \%$

Brush $=41 / 47=87.23 \%$ 
The $100 \%$ accuracies for agroforestry and pine forest, respectively, were expected given that these sample sites were identified while groundtruthing. They were not represented in the randomly generated points, so they were manually included thus explaining the high accuracies.

To explain the difference between user's and producer's accuracy, consider the following example. The user's accuracy for agroforestry was 59.26\%. A person on the ground in Cinco Pinos will find that $59.26 \%$ of the time when the map says an area is agroforestry will it in fact be agroforestry. From personal observations, agroforestry systems in Cinco Pinos have many of the same characteristics as TDF, as well as cultivated, pasture, and brush areas. They also exhibit variation in canopy height and cover. For example, an agroforestry system with dense canopy cover could appear spectrally similar to TDF cover, while an agroforestry system with sparse canopy cover has the potential to overlap spectrally with cultivated areas, brush, and even pasture during wet season (Jennings et al. 1999). It is suggested that only the agroforestry systems with canopy covers less dense than intact TDF, yet denser than crop, brush, or pasture grass ground cover were accurately classified. A similar effect could describe some of the error detected for all of the land classes, but more so for agroforestry given the similarities to the TDF class.

Two factors determine the relatively low accuracy of the pine forest class. The first is the low percentage of land class representation. Pine accounts for less than 5\% of the forest inventory in the region (Perez et al. 2007) and less than $0.55 \%$ of the entire landscape in 2011. The second factor is the small size of the pine stand in which I was 
able to retrieve sample points. The stands were each $\leq 2$ ha and may not have provided data robust enough to create quality training-sites. 


\section{CHAPTER 5 - DISCUSSION}

The results of the LULCC assessment indicate that the majority of the initial deforestation of Cinco Pinos took place before 1985. The change matrix for 1985 to 1990 shows that 1434 ha of TDF was present at the beginning of our study. If Cinco Pinos had once been forested with 6300 ha of TDF as the vegetation zones of Nicaragua indicate, over $75 \%$ of it had already been converted before 1985 (Salas Estrada 1993). Had Landsat 5 TM imagery been available for northern Nicaragua before 1985, it would have been incorporated into the analysis. Figure 5.1 shows the variation in hectares of TDF, cultivated, and pasture land classes over the 26-year period.

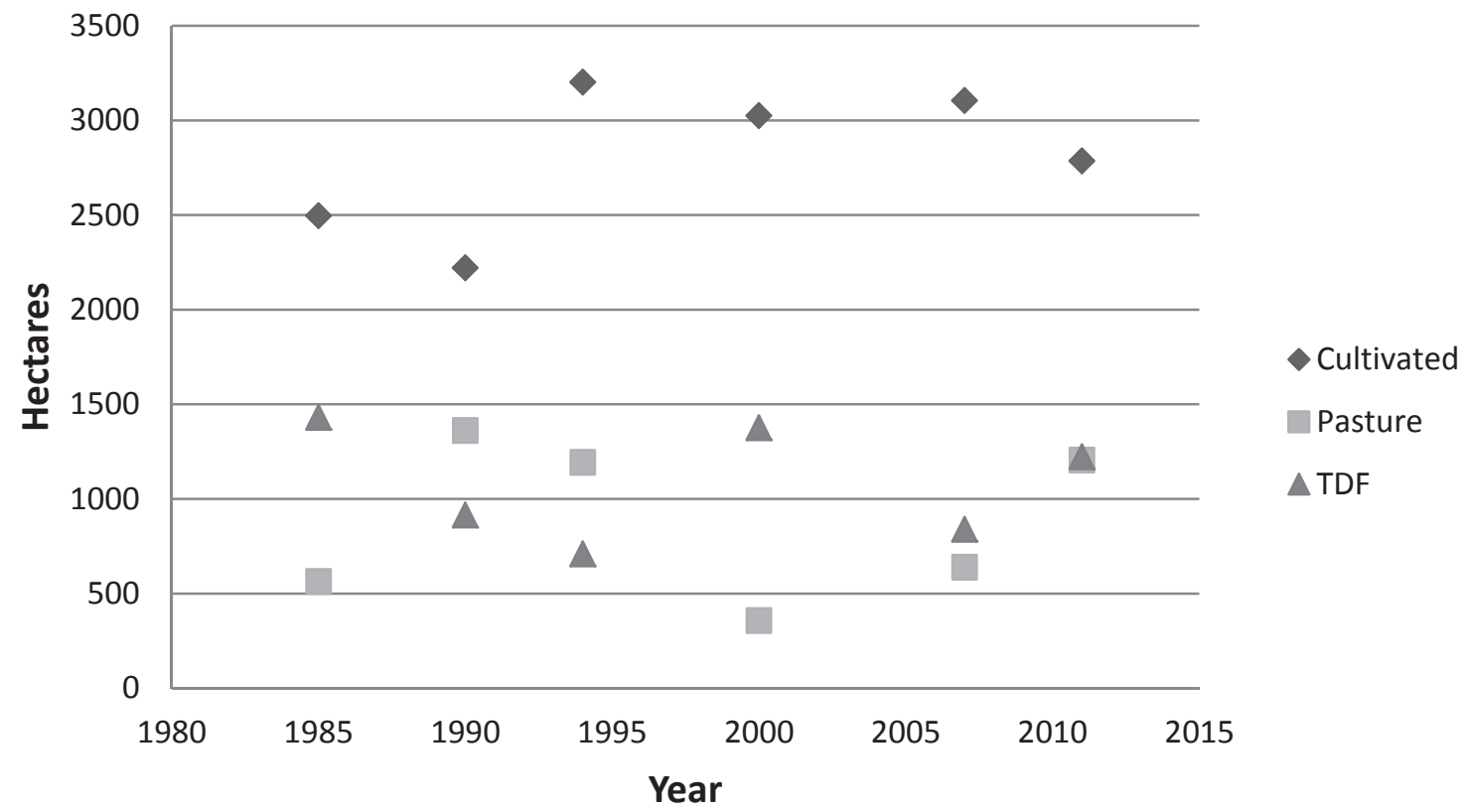

Figure 5.1. LULCC in hectares in Cinco Pinos for TDF, cultivated, and pasture from 1985-2011. 
Before European discovery, western Nicaragua was populated by indigenous people related to Maya and Aztec ancestors suggesting that people had inhabited the Pacific coastal region for thousands of years, however their effect on the landscape in Cinco Pinos is unknown (Library of Congress Online Catalog 2012). The first people of mixed descent (mestizos) to settle in Los Cuatro Santos is believed to be a result of Honduran immigrants escaping the economic collapse of 1873 following a default of external debt (Reinhart and Rogoff 2010). These were the people whom established the town of Cinco Pinos. These early settlers began clearing trees to cultivate basic grains, but populations were small.

The first significant deforestation in Cinco Pinos likely occurred between 1950 and 1970 when Nicaraguan electric power capacity expanded rapidly and demand for utility poles rose sharply (Library of Congress Online Catalog 2012). Personal communications I had with Cinco Pinos residents indicate the 1950s as the years when forest removal began for expansion of utility infrastructure targeting the abundance of timber offered by large old-growth TDFs. Additional historical dialogue points to the expansion of the cotton industry in the 1950s. Large agriculture producers began exploiting the central Pacific coast for cotton cultivation, especially in the fertile volcanic soils of Chinandega, to cash in on the growing export. When cotton plantations began to develop in the Rancherias and Villa Salvadorita zones of Chinandega, the people of these lands were displaced north towards the border of Honduras, some settling in the municipality of Cinco Pinos (Cuenta del Milenio 2008). The arrival of displaced farmers could explain early deforestation in the municipality as 
well.

Following the Sandinista Revolution of 1979, the brutal Contra war continued until 1989 claiming an estimated 40,000 casualties (Library of Congress Online Catalog 2012). Experts observed significant declines in deforestation throughout the country between 1983 and 1989, but noted an increase in forest clearing with the end of the civil war (Maldidier and Antillón 1993). From 1990 to 1994, substantial TDF conversion (204.48 ha) was observed in Cinco Pinos, but the effect the war had on deforestation in this region is not entirely clear. Men returning from combat to the farms could explain, in part, the deforestation of 1990 to 1994. In 1998 Hurricane Mitch devastated Honduras and Nicaragua causing billions of dollars in damage and nearly 9000 deaths throughout Central America (Guinau et al. 2005). The crippling storm cost Nicaragua approximately $45 \%$ of GNP (IPCC 2001). Thirty-two percent of the population of Cinco Pinos and neighboring San Francisco experienced property loss or damage as a result of flooding and landslides associated with Hurricane Mitch (Solidaridad Internacional 2001). In just ten days, intense rains from the hurricane brought $1597 \mathrm{~mm}$ of rain to Chinandega, almost $200 \mathrm{~mm}$ more than the mean annual rainfall (Guinau et al. 2005). On a single day (October 30, 1998), $485 \mathrm{~mm}$ of rain fell on northern Chinandega (INETER 1998). As a result of these intense rains, landslides in Cinco Pinos were triggered throughout the hillsides damaging property leaving many homeless. Around 1994, TDF cover in Cinco Pinos was at the lowest number of ha according to the LULCC assessment. The deforested mountainsides in addition to degraded soil from poor agricultural practices increased soil erosion processes that led 
to the high landslide susceptibility during the downpours of Hurricane Mitch (Perez et al. 2007). Following the catastrophe, foreign and domestic aid organizations provided relief to the region with access to potable water, food, and shelter. The importance of trees and maintaining forests to mitigate future landslides was quickly brought to the attention of farmers and local government. Large-scale reforestation efforts funded by the United Nations Development Program were undertaken to restore the degraded landscape in the years following the hurricane. The goal of the first phase of the project was to reforest 200 ha and develop agroforestry practices in 60 farms (Dolmus 2012). The ecological rehabilitations that followed the disaster of 1998 provide partial explanation for the reversal of TDF conversion as well as the increase in agroforestry systems evident in the LULCC assessment.

It is probable that the more recent forest conversions are a result of increasing population pressure. To some degree, anthropogenic activity has always been a factor in the deforestation of Cinco Pinos beginning with the first migrants from Honduras clearing land to cultivate. However, in the past few decades the local environment has been placed under increasing population pressure (Pallàs et al. 2004). Official population data for Cinco Pinos is available only for 1995 and 2005 (INIDE 2012); however, a local census estimated a population of 7672 people in 2012 . The population increased by $18.9 \%$ between 1995 and 2012. While TDF cover increased by roughly 100 ha between 2007 and 2012, it is unlikely that a population growing at this rate will be able to mitigate future forest clearing unless the local agricultural practices change to incorporate more agroforestry systems in addition to major reforestation efforts. 


\section{CHAPTER 6 - CONCLUSION}

Deforestation of TDF in the municipality of San Juan de Cinco Pinos began before 1985. Since then, TDF cover has seen both increases and decreases due to various socioeconomic factors and historical events, but a net loss of 210.51 ha was observed over a 26-year period. The majority of TDF loss since 1985 was a result of forest conversion to agricultural and pastoral land. If the TDF of Cinco Pinos continues to be converted to alternate land uses at a rate of approximately 10 ha per year, the local people face the prospect of losing what remains of their TDF in a few decades. However, results of the LULCC analysis (Figure 5.1) could also indicate a tapering off of TDF conversion. Since the mid-90s, deforestation of TDF in Cinco Pinos has remained moderately constant. This leveling off of LULCC could be attributed to livelihoods being supported by remittances as a result of out-migration of labor obtaining employment in neighboring Central American countries as well as the U.S. and Spain.

While the people of Cinco Pinos face tremendous obstacles including increasing population pressure, natural hazards, and ecological degradation, I know that they understand the importance of healthy forests and are resilient enough to find an enduring solution to the problems they face. It is my hope that this assessment will serve both as a tool to the people of Cinco Pinos to better understand how and where changes are occurring in their TDF, and as a baseline for future studies and conservation efforts throughout the region. 


\section{WORKS CITED}

Anderson, James Richard. A land use and land cover classification system for use with remote sensor data. Vol. 964. US Government Printing Office, 1976.

Augenstein, Eric Williams. "Evaluation of SPOT HRV-XS Data for Kelp Resource Inventories." Photogrammetric Engineering and Remote Sensing 57.5 (1991): 501.

Bishop, Yvonne M., Stephen E. Fienberg, and Paul Holland. Discrete Multivariate Analysis: Theory and Practice. Cambridge: MIT Press, 1975.

CIA (Central Intelligence Agency). The World Factbook: Nicaragua, https://www.cia.gov/library/publications/the-world-factbook/geos/nu.html (accessed November 14, 2012).

Congalton, Russell G., and Kass Green. Assessing the accuracy of remotely sensed data: principles and practices. CRC, 2008.

Cuenta del Milenio. "Consultancy Services for the Feasibility Study, Environmental Assessment and Final Design of the Secondary Road Rehabilitation Project," Millenium Challenge Corporation. http://www.cuentadelmilenio.org.ni/cedoc/03transp/caminos/fd/s3/Final\%20Design \%20Report\%20S3.pdf (accessed November 8, 2012).

Dirzo, Rodolfo, Hillary S. Young, Harold A. Mooney, and Gerardo Ceballos. Seasonally dry tropical forests. Island Press, 2011.

Dolmus, Ramon Cruz. "Exitoso Proyecto de Municipio Verde: Reforestan Tramo Entre Santo Tomas y Cinco Pinos." El Nuevo Diario March 25, 2002, http://archivo.elnuevodiario.com.ni/2002/junio/25-junio2002/departamentos/departamentos1.html.

ENABAS. "Division Politica de Nicaragua," Empresa Nicaragüense de Alimentos Básicos. http://www.enabas.gob.ni/enabas (accessed November 14, 2012).

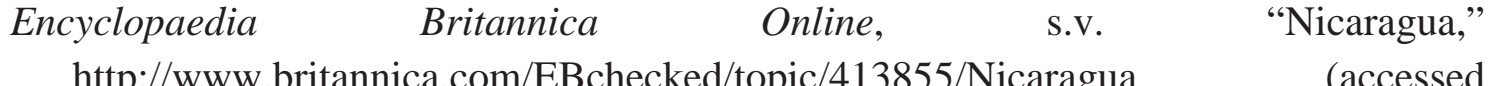
November 1, 2012).

ERDAS Field Guide, Norcross, GA: ERDAS, Inc. 2010. 
ESRI, DeLorme, NAVTEQ, "World Terrain Base," http://www.esri.com/software/arcgis/arcgis-online-map-and-geoservices/mapservices (accessed November 19, 2012).

Guinau, Marta, Raimon Pallàs, and Joan Manuel Vilaplana. "A feasible methodology for landslide susceptibility assessment in developing countries: A case-study of NW Nicaragua after Hurricane Mitch.” Engineering Geology 80.3 (2005): 316-327.

Holdridge, Leslie Ransselaer “Life zone ecology.” Life Zone Ecology. (rev. ed.) (1967).

INETER. "Las Lluvias del Siglo en Nicaragua," Instituto Nicaraguense de Estudios Territoriales. (1998): 159.

INETER. "Municipios de Nicaragua," Instituto Nicaraguense de Estudios Territoriales. http://www.ineter.gob.ni (accessed November 21, 2012).

INIDE. "VIII Censo de Poblacion y IV de Vivienda," Instituto Nacional de Informacion de Desarrollo. http://www.inide.gob.ni/censos2005/sensibilizacion.pdf (accessed November 8, 2012).

Jennings, S.B., N. D. Brown, and D. Sheil. "Assessing forest canopies and understory illumination: canopy closure, canopy cover and other measures." Forestry 72.1 (1999): 59-74.

Jensen, John R. Introductory Digital Image Processing: A remote sensing perspective. $3^{\text {rd }}$ ed. Upper Saddle River, NJ: Prentice-Hall Inc., 2005.

Library of Congress Online Catalog, s.v. A Country Study: Nicaragua, http://lcweb2.loc.gov/frd/cs/nitoc.html (accessed November 15, 2012)

Maldidier, Cristóbal, and Tupac Antillón. "Tendencias actuales de la frontera agricola en Nicaragua." UCA (1993).

Miles, Lera, Adrian C. Newton, Ruth S. DeFries, Corinna Ravilious, Ian May, Simon Blyth, Valerie Kapos, et al. "A global overview of the conservation status of tropical dry forests." Journal of Biogeography 33, no. 3 (2006): 491-505.

Pallàs, Raimon, Joan Manuel Vilaplana, Marta Guinau, Ester Falgàs, Xavier Alemany, and Angélica Muñoz. "A pragmatic approach to debris flow hazard mapping in areas affected by Hurricane Mitch: example from NW Nicaragua." Engineering Geology 72, no. 1 (2004): 57-72. 
Perez, Carlos J., Raffaele Vignola, and Hernán Perez. "Community based adaptation to climate variability and change in agriculture and water resources in the dry tropics of Nicaragua: The Case of San Pedro del Norte." CATIE (2007).

Press, William H., Brian P. Flannery, Saul A. Teukolsky, and William T. Vetterling. Numerical Recipes in FORTRAN 77: Volume 1, Volume 1 of Fortran Numerical Recipes: The Art of Scientific Computing. Vol. 1. Cambridge University Press, 1992.

Ramirez, P. O. "Climate, Climate Variability and Climate Change in Central America: Review of experiences, actors and needs in tropical forest climate change vulnerability and adaptation in Central America. Consultancy Report." CATIE (2005).

Reinhart, Carmen M., and Kenneth S. Rogoff. From financial crash to debt crisis. No. w15795. National Bureau of Economic Research, 2010.

Rutchey, Ken, and Les Vilcheck. "Development of an Everglades vegetation map using a SPOT image and the Global Positioning System." Photogrammetric Engineering and Remote Sensing 60.6 (1994): 767-775.

Salas Estrada, Juan B. Árboles de Nicaragua. Managua: Instituto Nicaragüense de Recursos Naturales y del Ambiente, IRENA, 1993.

Sánchez-Azofeifa, G. Arturo, Mauricio Quesada, Jon Paul Rodríguez, Jafet M. Nassar, Kathryn E. Stoner, Alicia Castillo, et al. "Research Priorities for Neotropical Dry Forests." Biotropica 37, no. 4 (2005): 477-485.

Siebert, Lee, and Tom Simkin. "Volcanoes of the world: An illustrated catalog of Holocene volcanoes and their eruptions." Smithsonian Institution, Global Volcanism Program, Digital Information Series GVP-3 (http://www. volcano. si. edu/world) (2002).

Silva, Rich. "Nicaragua's San Cristobal Volcano Erupts." The Nicaragua Dispatch, September 8, 2012, http://www.nicaraguadispatch.com/news/2012/09/nicaraguassan-cristobal-volcano-erupts/5172.

Singh, Ashbindu, and Andrew Harrison. "Standardized principal components." International Journal of Remote Sensing 6.6 (1985): 883-896. 
Solidaridad Internacional. "Estrategias participativas para el desarrollo rural en seis municipios del norte del Departamento de Chinandega." Proyecto de Cooperación Internacional desarrollado conjuntamente con el Instituto de Capacitación e Investigación para el Desarrollo Rural Integral (ICIDRI) de la Universidad Politécnica de Nicaragua (UPOLI). Unpublished Report. Managua, Nicaragua. (2001).

Story, Michael, and Russell G. Congalton. "Accuracy assessment: a user's perspective." Photogrammetric Engineering and remote sensing 52.3 (1986): 397-399.

Taylor, B. W. "An outline of the vegetation of Nicaragua." The Journal of Ecology (1963): 27-54.

Wang, Fangju. "A knowledge-based vision system for detecting land changes at urban fringes." Geoscience and Remote Sensing 31.1 (1993): 136-145.

WWF. "WWF Wildfinder," World Wildlife Fund. http://worldwildlife.org/science/wildfinder/ (accessed November 3, 2012).

Zeledon, Esther B., and N. Maggi Kelly. "Understanding large-scale deforestation in southern Jinotega, Nicaragua from 1978 to 1999 through the examination of changes in land use and land cover." Journal of Environmental Management 90.9 (2009): 2866-2872.

Zhao, Guang, and Ann L. Maclean. "A comparison of canonical discriminant analysis and principal component analysis for spectral transformation." $P E \& R S$, Photogrammetric Engineering \& Remote Sensing 66.7 (2000): 841-847. 


\section{APPENDIX A}

\section{Permissions:}

\section{Figure 2.1}

The World Factbook is in the public domain and may be used freely by anyone at anytime without seeking permission. However, US Code (Section 403m) prohibits use of the CIA seal in a manner which implies that the CIA approved, endorsed, or authorized such use.

\section{Figure 2.2}

Materials of the ENABAS public domain are not copyrighted and no permission is needed to copy them.

\section{Figure 2.3, 2.4, and 2.5}

\section{Dear Jonathan Malette,}

Thank you for your email request.

Permission is granted for you to use the material requested for your thesis/dissertation subject to the usual acknowledgements and on the understanding that you will reapply for permission if you wish to distribute or publish your thesis/dissertation commercially.

Permission is granted solely for use in conjunction with the thesis, and the article may not be posted online separately.

Any third party material is expressly excluded from this permission. If any material appears within the article with credit to another source, authorisation from that source must be obtained.

Best Wishes,

Verity Butler

Permissions Co-ordinator

Wiley

The Atrium, Southern Gate

Chichester, PO19 8SQ 
$U K$

www.wiley.com

vbutler@wiley.com

\section{Figure 3.1}

Esri grants the recipient of the Esri information contained within the esri.com Web site the right to freely reproduce, redistribute, rebroadcast, and/or retransmit this information for personal, noncommercial purposes, including teaching, classroom use, scholarship, and/or research, subject to the fair use rights enumerated in sections 107 and 108 of the Copyright Act (Title 17 of the United States Code). All copies, whether in whole or in part, shall include the appropriate Esri copyright notice. 


\section{Appendix B}

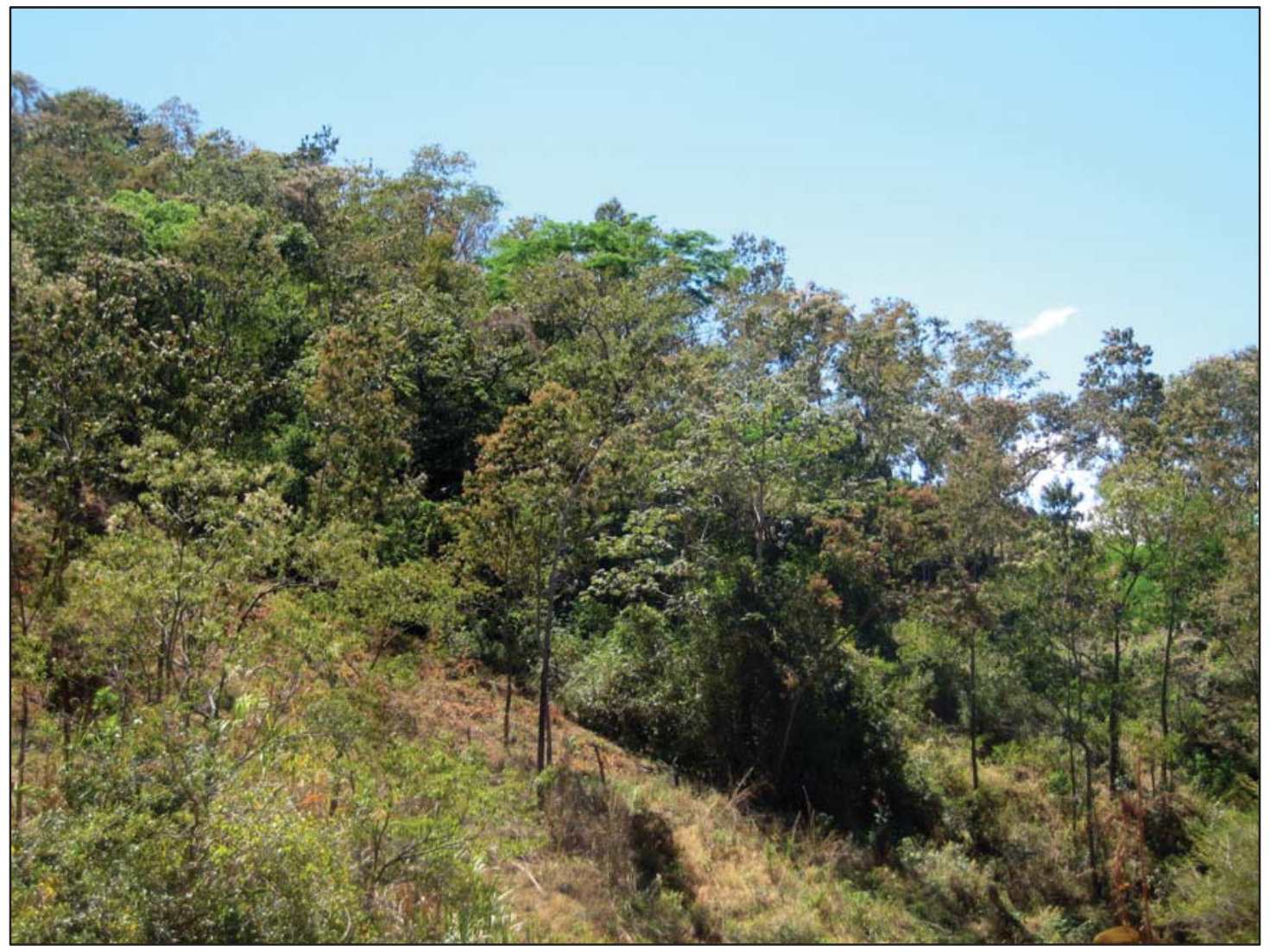

Figure B.1. Fragmented TDF stand in Cinco Pinos. Photo by Jonathan W. Malette. 


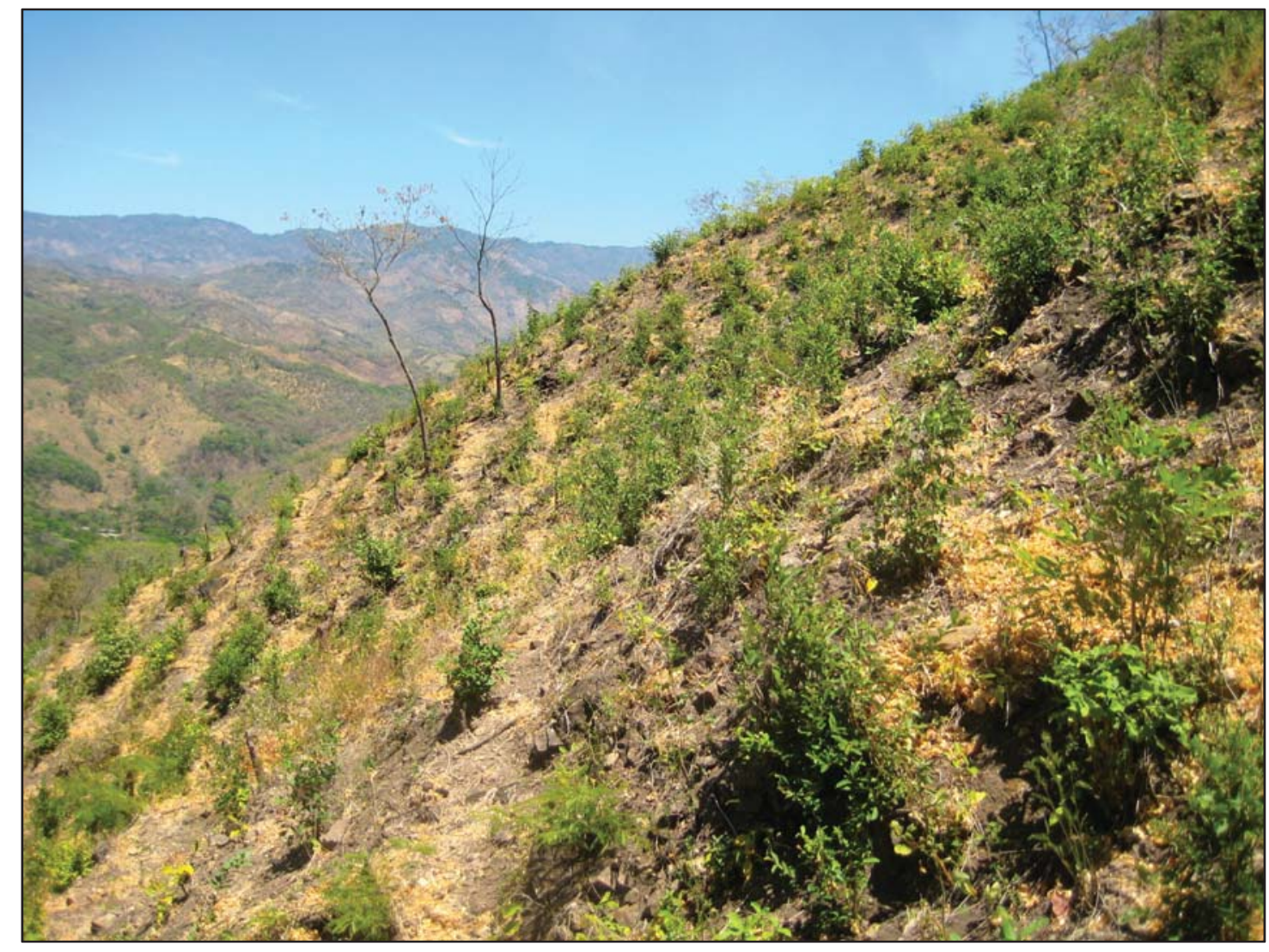

Figure B.2. Fallow cultivated area in Cinco Pinos. Photo by Jonathan W. Malette. 


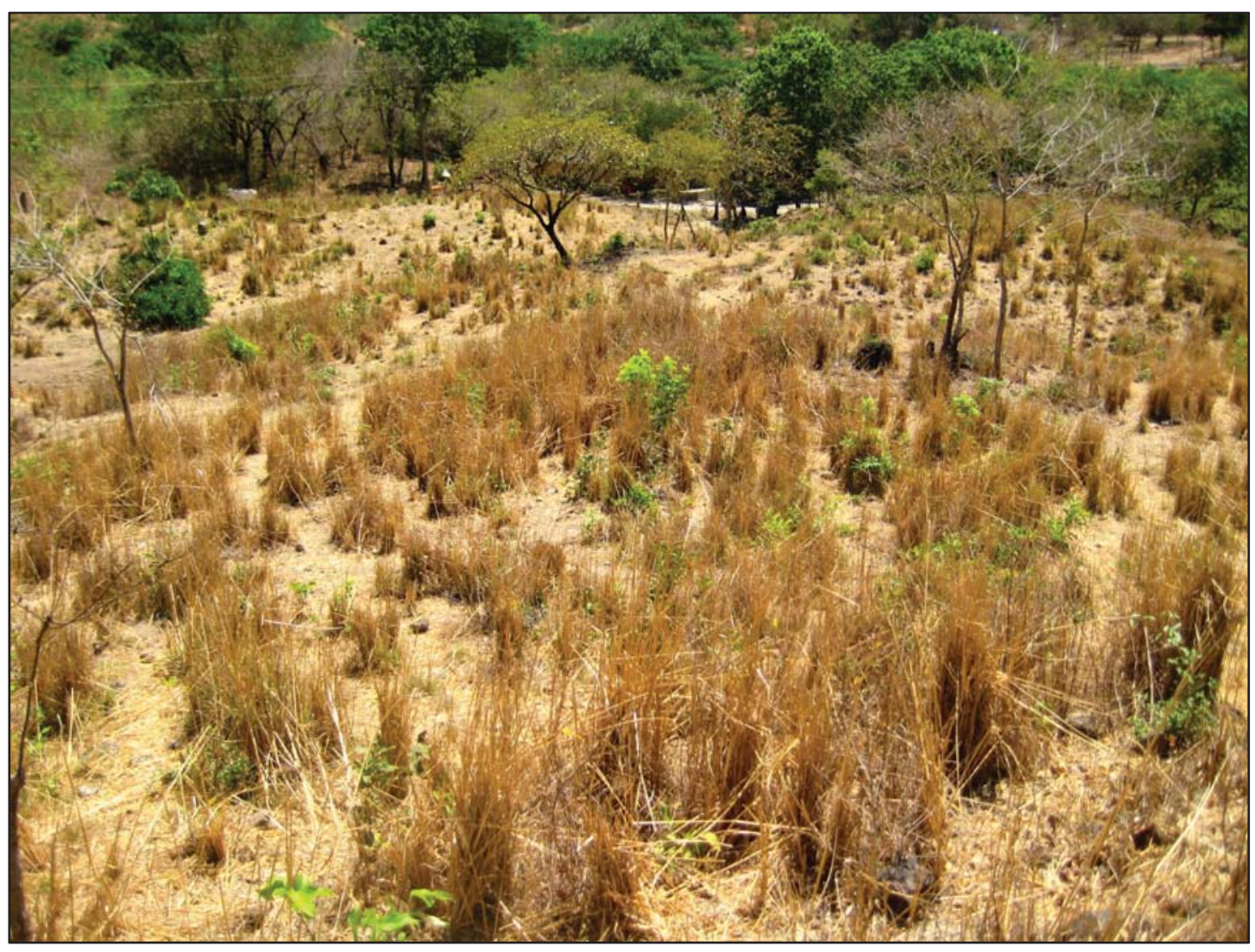

Figure B.3. Planted pasture grasses in Cinco Pinos. Photo by Jonathan W. Malette. 


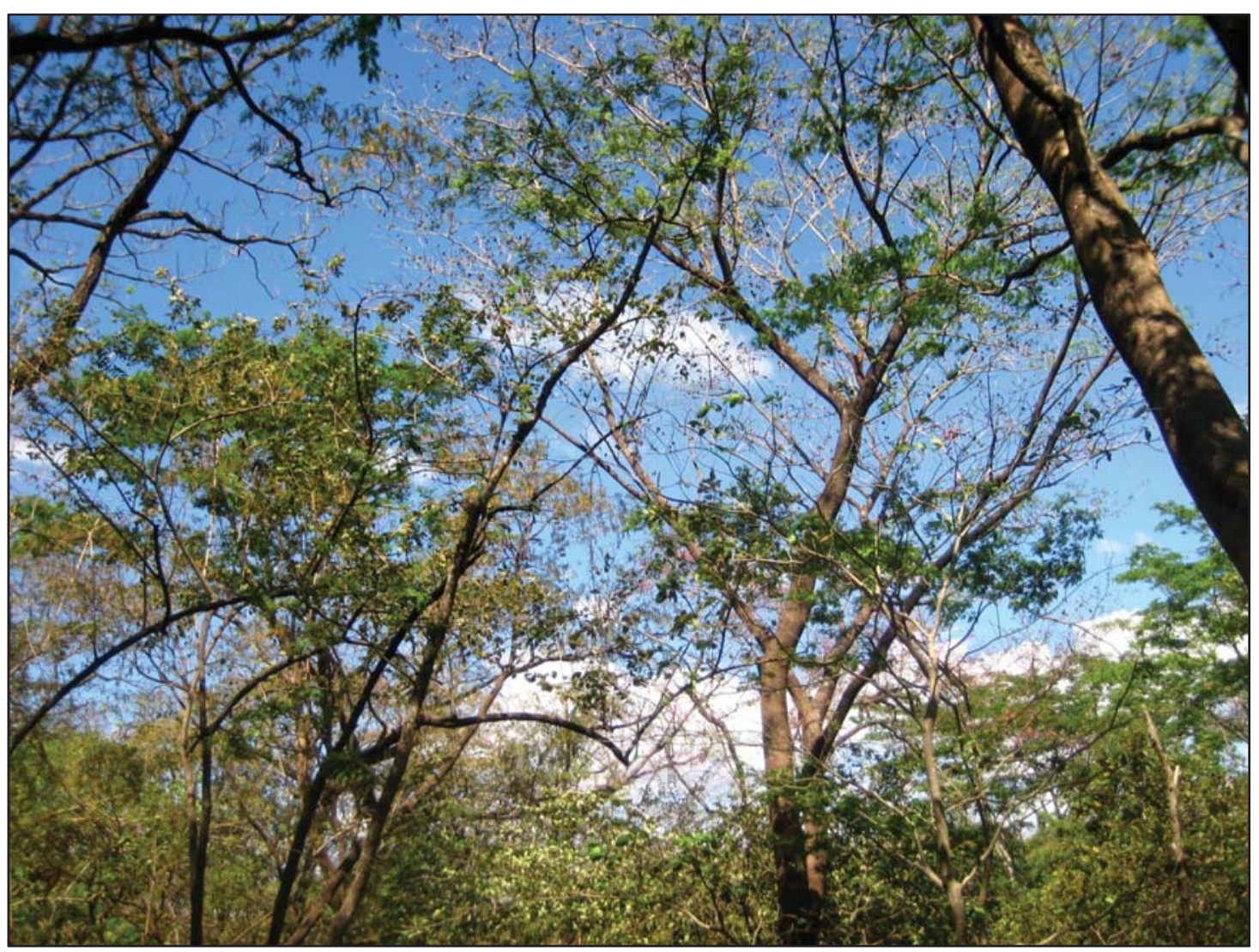

Figure B.4. Agroforestry system of TDF under planted with coffee in Cinco Pinos. Photo by Jonathan W. Malette. 


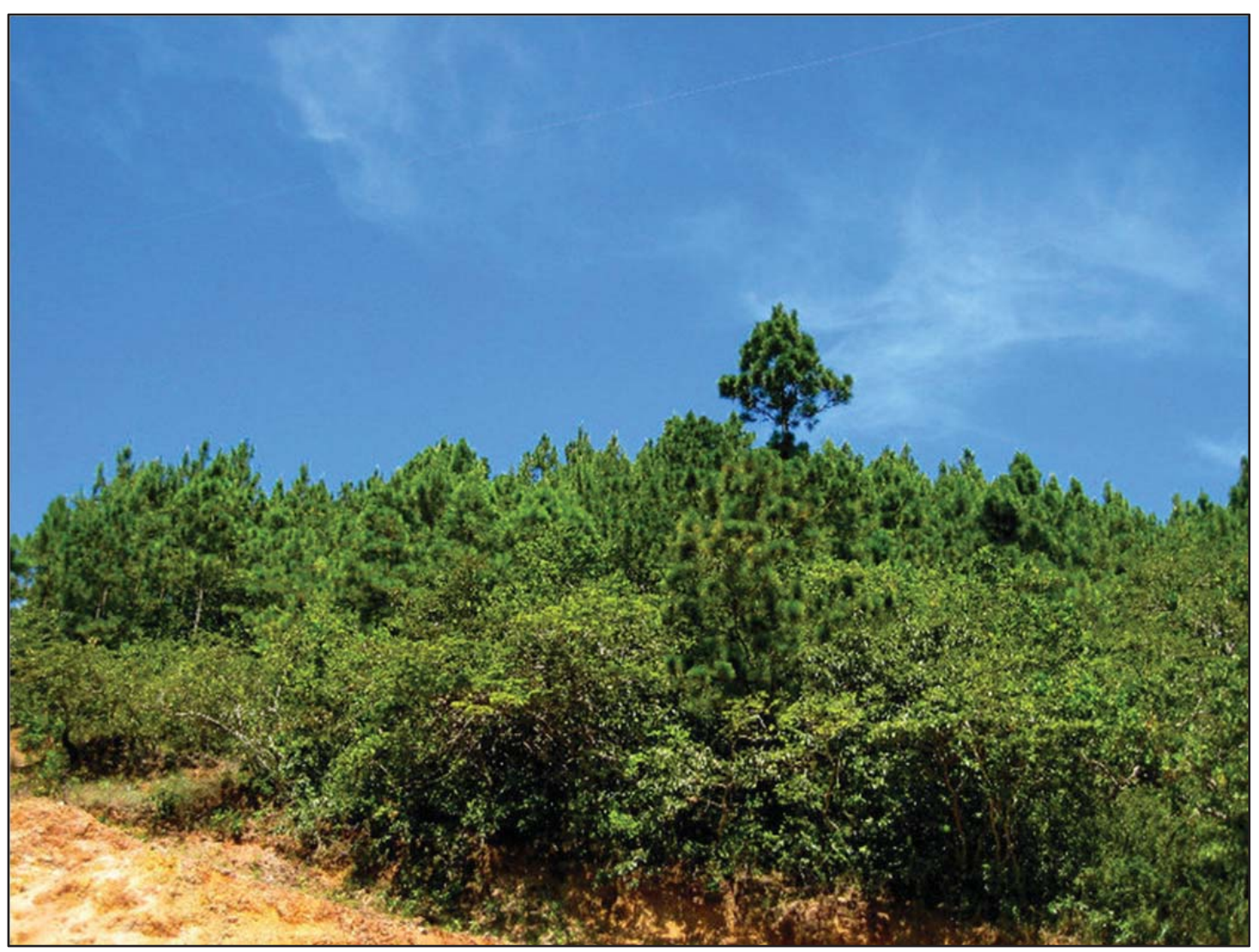

Figure B.5. Plantation pine (Pinus oocarpa) in Cinco Pinos. Photo by Jonathan W. Malette. 


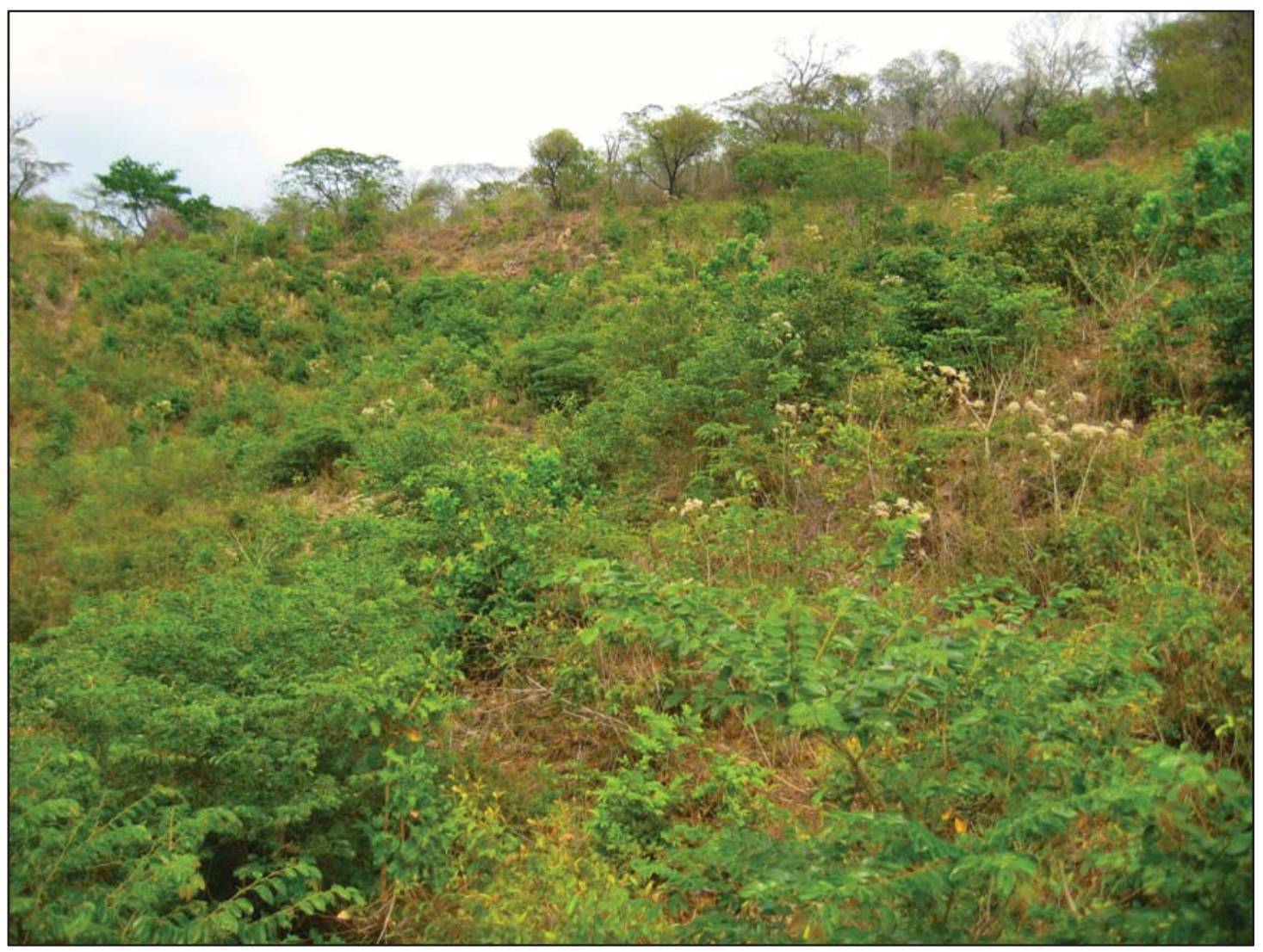

Figure B.6. Area allowed to return to shrub and brush in Cinco Pinos. Photo by Jonathan W. Malette. 